Review

\title{
Recent advances on the development of wound dressings for diabetic foot ulcer treatment-A review
}

\author{
Liane I.F. Moura $^{\mathrm{a}, \mathrm{b}}$, Ana M.A. Dias $^{\mathrm{b}}$, Eugénia Carvalho ${ }^{\mathrm{a}, \mathrm{c}, *}$, Hermínio C. de Sousa ${ }^{\mathrm{b}, *}$ \\ ${ }^{a}$ Center for Neuroscience and Cell Biology, University of Coimbra, 3004-517 Coimbra, Portugal \\ ${ }^{\mathrm{b}}$ CIEPQPF, Chemical Engineering Department, FCTUC, University of Coimbra, Rua Sílvio Lima, Pólo II - Pinhal de Marrocos, 3030-790 Coimbra, Portugal \\ ' APDP, The Portuguese Diabetes Association, Rua do Salitre, No. 118-120, 1250-203 Lisboa, Portugal
}

\section{A R T I C L E I N F O}

\section{Article history:}

Received 14 November 2012

Received in revised form 6 March 2013

Accepted 21 March 2013

Available online 27 March 2013

\section{Keywords:}

Diabetes

Diabetic foot ulcers

Wound healing

Wound dressings

Natural and synthetic polymers

\begin{abstract}
A B S T R A C T
Diabetic foot ulcers (DFUs) are a chronic, non-healing complication of diabetes that lead to high hospital costs and, in extreme cases, to amputation. Diabetic neuropathy, peripheral vascular disease, abnormal cellular and cytokine/chemokine activity are among the main factors that hinder diabetic wound repair. DFUs represent a current and important challenge in the development of novel and efficient wound dressings. In general, an ideal wound dressing should provide a moist wound environment, offer protection from secondary infections, remove wound exudate and promote tissue regeneration. However, no existing dressing fulfills all the requirements associated with DFU treatment and the choice of the correct dressing depends on the wound type and stage, injury extension, patient condition and the tissues involved. Currently, there are different types of commercially available wound dressings that can be used for DFU treatment which differ on their application modes, materials, shape and on the methods employed for production. Dressing materials can include natural, modified and synthetic polymers, as well as their mixtures or combinations, processed in the form of films, foams, hydrocolloids and hydrogels. Moreover, wound dressings may be employed as medicated systems, through the delivery of healing enhancers and therapeutic substances (drugs, growth factors, peptides, stem cells and/or other bioactive substances). This work reviews the state of the art and the most recent advances in the development of wound dressings for DFU treatment. Special emphasis is given to systems employing new polymeric biomaterials, and to the latest and innovative therapeutic strategies and delivery approaches.
\end{abstract}

(c) 2013 Acta Materialia Inc. Published by Elsevier Ltd. All rights reserved.

\section{Introduction}

Diabetes mellitus is one of the most prevalent chronic diseases: in 2010, it was estimated that 285 million adults worldwide had diabetes and this figure is expected to rise to 439 million by $2030[1,2]$. In North America and Europe, the number of adults with diabetes is expected to increase by $42.4 \%$ and $20 \%$, respectively, and a major burst in Africa is predicted, with the number of adults with diabetes expected to increase by $98.1 \%$ from 2010 to 2030 [1,2] (Fig. 1). The main factors responsible for the increase in the number of patients with diabetes are the growth and aging of the population and changes in lifestyle [1,3]. Diabetes mellitus is a metabolic disorder characterized by high levels of glucose in serum and by changes in carbohydrate, lipid and protein metabolism which are caused by alterations in insulin secretion, in insulin action or in both of these processes [4]. Diabetes can be classified into

\footnotetext{
* Corresponding authors. Address: Center for Neuroscience and Cell Biology, University of Coimbra, 3004-517 Coimbra, Portugal (E. Carvalho).

E-mail addresses: ecarvalh@cnc.uc.pt (E. Carvalho), hsousa@eq.uc.pt (H.C. de Sousa).
}

type 1, type 2 and gestational diabetes. Type 1, insulin-dependent diabetes mellitus (IDDM), or juvenile-onset diabetes, is characterized by pancreatic $\beta$-cell destruction, leading to absolute insulin deficiency and, consequently, to the total dependence on exogenous insulin to sustain life [4,5]. The incidence of type 1 diabetes is usually higher under the age of 15 though only $20-50 \%$ of patients are diagnosed before this age. In addition, the Caucasian population tends to present a higher risk for type 1 diabetes when compared to all other ethnic groups [6]. Type 2 diabetes mellitus, also known as non-insulin-dependent diabetes mellitus (NIDDM), or adult-onset diabetes, is characterized by insulin resistance which may be combined with relatively reduced insulin secretion levels. Type 2 diabetes affects approximately $90 \%$ of all diabetic patients and its main risk factors are high plasma glucose concentrations in the fasting state and after an oral glucose load, being overweight and a sedentary lifestyle [7]. However, this type of diabetes can be delayed or prevented by a proper nutrition regime and by regular physical exercise $[8,9]$. Finally, gestational diabetes or impaired glucose intolerance, which is first diagnosed during pregnancy, is defined as carbohydrate intolerance during gestation [10]. Gestational diabetes affects approximately $14 \%$ of pregnancies and 


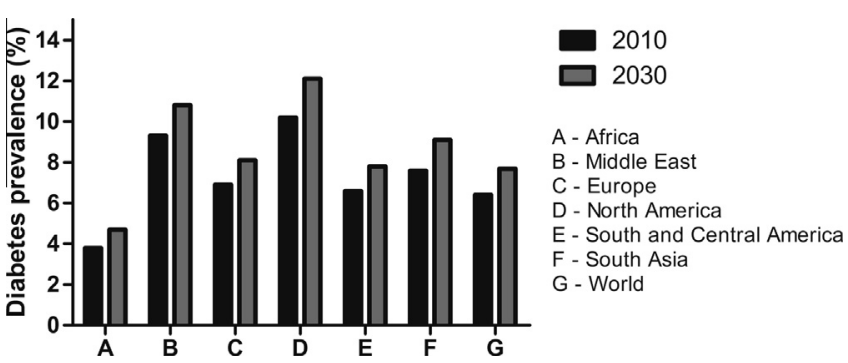

Fig. 1. Diabetes prevalence in the world, in 2010 and 2030 (adapted from Shaw et al. [1]).

is also an important risk factor for type 2 diabetes in women $[11,12]$.

In addition and among other problems, diabetic patients are more likely to develop obesity [13-16], coronary heart disease, stroke [17-19], diabetic nephropathy [20-23], diabetic retinopathy [24-27] and diabetic neuropathy [28-31]. These diseases are largely responsible for the observed high mortality rates in diabetic patients.

\section{Diabetic foot ulcers (DFUs) and impaired wound healing}

Wound healing is a complex process that involves the simultaneous actuation of soluble mediators, blood cells, extracellular matrix (ECM) and parenchymal cells. This process can be divided into several phases: homeostasis/coagulation, inflammation, proliferation (granulation tissue formation), re-epithelialization and remodeling $[32,33]$. These phases are not typically associated with a rigorous and well-defined period of time and may overlap [30,34-36]. The transition between phases usually depends on the maturation and differentiation of keratinocytes, fibroblasts, mast cells and macrophages which are the most important cells involved in the wound healing process [37-39].

After tissue injury, a fibrin plug is formed in order to re-establish homeostasis, and aggregated platelets secrete several growth factors and cytokines (e.g. transforming growth factor beta (TGF$\beta$ ) and monocyte chemoattractant protein 1 (MCP-1)) that recruit neutrophils and monocytes to the wound site. These inflammatory cells induce the expression of colony-stimulating factor 1 (CSF-1), tumor necrosis factor $\alpha$ (TNF- $\alpha$ ) and platelet-derived growth factor (PDGF) which are extremely important for the first phase of new tissue formation process $[40,41]$. Re-epithelialization usually begins a few hours after injury. In response to these growth factors, keratinocytes and activated fibroblasts migrate from the wound edges into the wound site where they proliferate and construct the ECM that will enhance wound closure [30,32]. The initial ECM is gradually replaced by a collagenous matrix with the formation of new blood vessels (angiogenesis) [38]. The angiogenic factors, such as fibroblast growth factor (FGF), vascular endothelial growth factor (VEGF) and PDGF induce angiogenesis by stimulating the production of basic fibroblast and of vascular endothelial growth factors by macrophages and endothelial cells [40,42]. Protease expression and activity are also necessary for the angiogenesis process $[38,42]$. When the wound area is completely filled with new granulation tissue, angiogenesis stops and the apoptosis of many new vessels is then started. The last phase of the wound healing process is characterized by the degradation of the previously formed granulation tissue and by dermis regeneration [39]. While acute wounds usually progress linearly through the different wound healing phases, the healing process in diabetic patients does not follow this timeline, but rather results in chronic nonhealing wounds that become stalled in one or more of the abovementioned healing phases $[35,43]$.
Chronic diabetic neuropathy, defined as temporary or permanent nerve tissue damage, is a common complication of diabetes which is characterized by a progressive loss of peripheral nerve fibers that is caused by a decreased blood flow and high glycemic levels $[29,44]$. The duration and intensity of the exposure to hyperglycemia strongly influences the severity of neuropathy [29]. Diabetic neuropathy can be classified as peripheral, autonomic, proximal or focal, depending on the affected body part $[45,46]$. It occurs in both type 1 and type 2 diabetes and is more frequent in older people. However, many diabetic patients may never develop neuropathy while others may develop this condition rather early $[46,47]$. On average, neuropathy symptoms begin to appear within 10-20 years of the diagnosis of diabetes, and approximately $50 \%$ of diabetic patients will develop nerve damage in some extent [48].

Diabetic neuropathy and peripheral vascular disease are usually the major factors involved in DFUs. These two factors may act alone, together, or in combination with other conditions such as microvascular disease, biomechanical abnormalities, limited joint mobility and increased susceptibility to infection $[48,49]$. Some studies report that the difficulties associated with DFU healing are mostly due to the excessive and persistent activity of metalloproteinases (MMPs) and/or due to low levels of MMP inhibitors $[50,51]$. In addition, ischemia and vascular disease usually reduce the healing capacity due to the reduced supply of oxygen and nutrients to the wound area [52]. There are also impaired granulocytic, chemotaxis and macrophage functions, as well as prolonged inflammation and deregulation of the neovascularization phase $[53,54]$. These issues are mainly due to impaired expression of growth and angiogenic factors, namely VEGF and PDGF [55]. Finally, there may be also nitric oxide abnormalities, collagen accumulation [56], abnormal migration and proliferation of fibroblasts and of keratinocytes [55], as well as accumulation of ECM components and their remodeling by MMPs [57]. Fig. 2 schematizes the phases and growth factors involved in diabetic wound healing processes in comparison with a regular wound.

In general, these chronic, non-healing neuropathic foot ulcers occur in around $15 \%$ of all the diabetic population [56] and are responsible for huge medical costs as well as significantly affecting patients' quality of life $[35,56,58]$. Once a DFU has developed there is an increased risk of wound progression that may ultimately lead to amputation (more than $85 \%$ of foot amputations in patients are caused by DFU) [49].

The medical treatment of DFU remains a challenge. A better understanding of the pathophysiology and molecular biology of diabetic wounds may help to find improved and more efficient solutions for their treatment. It is currently accepted that DFU therapies should be directed to actively promoting wound healing by correcting the expression of those biological factors which are important in the healing process [59]. Table 1 describes some of the most recent approaches that have been used to stimulate DFU healing. However, to date, their efficacies and/or their application mode have not been sufficient to guarantee adequate DFU healing.

Like for acute wounds, it is already well established that to enhance DFU healing processes, wounds should be dressed with adequate biomaterials in order to protect the long-term healing from contamination/infection, to prevent wound dissection (providing an ideal moist environment to help wound closure) and, in the case of medicated dressings, to provide a sustained and effective release of the applied bioactive substances, as well as to prevent their rapid degradation during the healing process $[60,61]$.

DFUs can be medically classified in a variety of ways but all of them define the ulcer in terms of its depth and the presence of osteomyelitis or gangrene $[62,63]$. As an example, the classification according to Wagner's system is based on the following grades: 

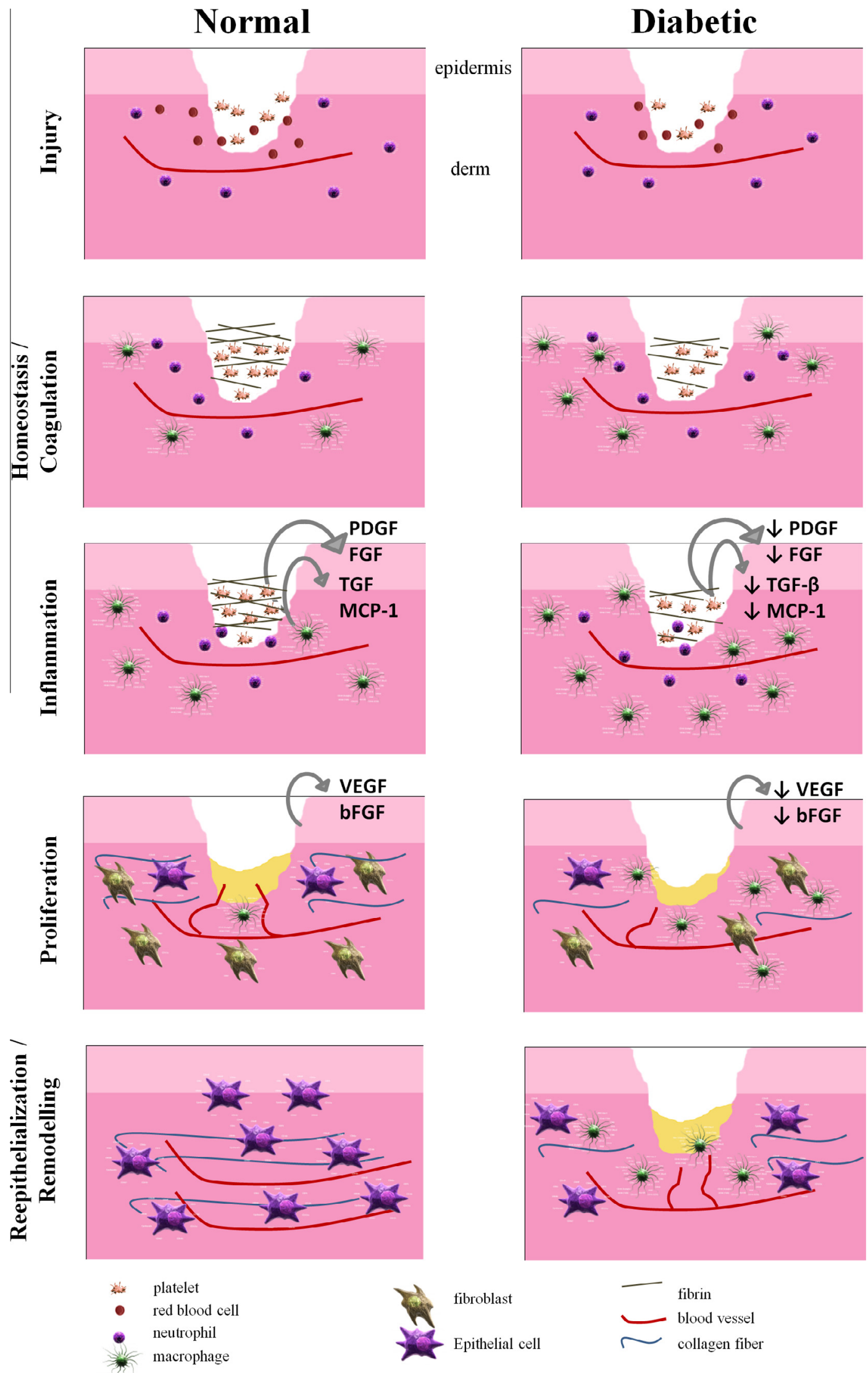

Fig. 2. Differences in the normal and diabetic wound healing phases (adapted from Beanes et al. 2003). 
Table 1

Some different and recently proposed approaches to improve DFU treatment.

\begin{tabular}{|c|c|c|c|c|}
\hline $\begin{array}{l}\text { Bioactive } \\
\text { substances }\end{array}$ & & Models used & Results & References \\
\hline \multirow[t]{4}{*}{ Growth factors } & VEGF & $\mathrm{db} / \mathrm{db}$ diabetic mice & $\begin{array}{l}\text { Enhanced neovascularization, mobilization of bone marrow-derived cells into the } \\
\text { wound site to accelerate wound healing }\end{array}$ & Galiano et al, 2004 [257] \\
\hline & PDGF & STZ diabetic rats & $\begin{array}{l}\text { Enhanced angiogenesis, cell proliferation and epithelialization. Formed thicker and } \\
\text { more highly organized collagen fiber deposition }\end{array}$ & Li et al, 2008 [258] \\
\hline & bFGF & Human patients with DFUs & $\begin{array}{l}\text { Reduction of } 75 \% \text { of wound area in treated patients. Stimulated granulation and } \\
\text { epithelization of tissues }\end{array}$ & Uchi et al, 2009 [259] \\
\hline & SDF- $1 \alpha$ & STZ diabetic mice & Increased EPC mobilization, homing and wound healing & Gallagher et al, 2007 [260] \\
\hline \multirow[t]{5}{*}{ Stem cells } & Bmscs & STZ diabetic rats & $\begin{array}{l}\text { Promoted healing and improved the wound breaking strength. In addition, it } \\
\text { increased collagen levels and TGF- } \beta \text {, KGF, EGF and VEGF expression }\end{array}$ & Kwon et al, 2008 [261] \\
\hline & CD133 ${ }^{+}$cells & STZ diabetic rats & $\begin{array}{l}\text { Accelerated wound closure and promoted angiogenesis through stimulation of } \\
\text { endothelial cell proliferation and migration }\end{array}$ & Barcelos et al, 2009 [262] \\
\hline & Human adipose-derived stromal cells & $\mathrm{db} / \mathrm{db}$ diabetic mice & $\begin{array}{l}\text { Increased wound closure and stimulated production of extracellular matrix proteins } \\
\text { and secreted souble factors }\end{array}$ & Amos et al, 2010 [263] \\
\hline & Embryonic stem cells & STZ diabetic rats & Reduced significantly wound size and increased expression of EGF and VEGF & Lee et al, 2011 [264] \\
\hline & EPCs & $\mathrm{db} / \mathrm{db}$ diabetic mice & Promoted wound healing and vascularity and induced expression of VEGF and bFGF & Asai et al, 2012 [265] \\
\hline \multirow[t]{4}{*}{ Gene therapy } & Adenoviral PDGF-B & $\mathrm{db} / \mathrm{db}$ diabetic mice & $\begin{array}{l}\text { Significantly enhanced wound repair and neovascularization. In addition, adenoviral- } \\
\text { PDGF-B stimulated EPC recruitment to the wound site }\end{array}$ & Keswani et al, 2004 [266] \\
\hline & Lentiviral-containing SDF- $1 \alpha$ & $\begin{array}{l}\text { STZ diabetic mice obese NOD/Ltj } \\
\text { mice }\end{array}$ & $\begin{array}{l}\text { Improved diabetic wound healing with completely epithelialization and increased } \\
\text { the granulation tissue }\end{array}$ & Badillo et al, 2007 [267] \\
\hline & Adenoviral-Hox B3 & $\mathrm{db} / \mathrm{db}$ diabetic mice & Accelerated wound healing in diabetic mice & Mohebali et al, 2008 [268] \\
\hline & $\begin{array}{l}\text { F-5 peptide (115-aa fragment of secreted } \\
\text { Hsp90 } \alpha \text { ) }\end{array}$ & $\mathrm{db} / \mathrm{db}$ diabetic mice & $\begin{array}{l}\text { Promoted diabetic wound closure through the recruitment of both epidermal and } \\
\text { dermal cells and promoting dermal cell migration }\end{array}$ & Cheng et al, 2011 [269] \\
\hline \multirow[t]{3}{*}{ Proteins } & Substance $\mathrm{P}$ & $\mathrm{db} / \mathrm{db}$ diabetic mice & $\begin{array}{l}\text { Enhanced wound repair and increased early inflammatory density in the healing } \\
\text { wounds }\end{array}$ & $\begin{array}{l}\text { Gibran et al, } 2002[270] \\
\text { Scott et al, } 2008[271]\end{array}$ \\
\hline & Erythropoietin & STZ diabetic rats & $\begin{array}{l}\text { Significantly reduced the time of total wound closure, increased micro vascular } \\
\text { density, VEGF, and hydroxyproline contents and reduced extent of apoptosis }\end{array}$ & Hamed et al, 2010 [272] \\
\hline & Insulin & STZ diabetic rats & Enhanced wound healing and stimulated a faster epithelialization & $\begin{array}{l}\text { Apikiglu-Rabus et al, } 2010 \\
\text { [273] }\end{array}$ \\
\hline \multirow[t]{5}{*}{ Natural products } & Lithospermun erythrorhison extract & $\mathrm{db} / \mathrm{db}$ diabetic mice & $\begin{array}{l}\text { Decreased vascular permeability, formation of granulation tissue and accelerated } \\
\text { wound healing }\end{array}$ & Fujita et al, 2003 [274] \\
\hline & $\begin{array}{l}\text { Aqueous extract of Rosmarinus officinalis } \\
\text { (Rosemary) }\end{array}$ & STZ diabetic rats & $\begin{array}{l}\text { Promoted ulcer healing accelerating the processes of tissue regeneration, } \\
\text { angiogenesis and inflammation }\end{array}$ & Lau et al, 2009[275] \\
\hline & Rehmanniae radix & Alloxan diabetic mice & $\begin{array}{l}\text { Reduced inflammation and enhancement of wound contraction, re-epithelialization } \\
\text { and regeneration of granulation tissue, angiogenesis and collagen deposition in the } \\
\text { treated wounds }\end{array}$ & Abu-al-Basal et al., 2010 [276] \\
\hline & Ampucare (polyherbal ingredient) & Alloxan diabetic rats & $\begin{array}{l}\text { Significantly reduced the wound size and bacterial count in wound site. Stimulated a } \\
\text { well organized fibrous tissue proliferation, epithelization and complete scar } \\
\text { formation }\end{array}$ & $\begin{array}{l}\text { Dwivedi and Chaudhary, } 2012 \\
\text { [277] }\end{array}$ \\
\hline & Ethanolic extract of Annona squamosa & STZ diabetic rats & $\begin{array}{l}\text { Enhanced rates of epithelialisation and wound contraction. Increased cellular } \\
\text { proliferation and collagen synthesis at the wound site }\end{array}$ & Ponrasu et al, 2012 [278] \\
\hline
\end{tabular}


grade 0 (no ulcer in a foot with a high-risk factor of complication); grade 1 (partial/full thickness ulcer); grade 2 (deep ulcer, penetrating down to ligaments and muscle, but no bone involvement); grade 3 (deep ulcer with cellulitis or abscess formation); grade 4 (localized gangrene); and grade 5 (extensive whole foot gangrene) [64]. The classification of DFUs is important as it may facilitate the choice of suitable dressing depending on the wound type and on its phase [65].

This choice depends on several factors that will be discussed in the following sections.

\section{Wound dressings for DFU treatment}

\subsection{Types and main characteristics of wound dressings}

Natural skin is considered the perfect wound dressing and therefore an ideal wound dressing should try to replicate its properties [66]. Historically, wound dressings were first considered to play only a passive and protective role in the healing process. However, in recent decades wound treatment has been revolutionized by the discovery that moist dressings can help wounds heal faster $[67,68]$. Furthermore, a moist wound environment is also an important factor to induce the proliferation and migration of fibroblasts and keratinocytes as well as to enhance collagen synthesis, leading to reduced scar formation $[69,70]$.

Besides assuring optimal moisture for wound environments, it is currently accepted that a wound dressing should also: (i) have the capacity to provide thermal insulation, gaseous exchange, and to help drainage and debris removal thus promoting tissue reconstruction processes; (ii) should be biocompatible and not provoke any allergic or immune response reaction; (iii) should protect the wound from secondary infections; and (iv) should be easily removed without causing trauma [66,71].

Due to the distinct characteristics of the different types of wounds and of each of the wound healing stages, there is no one single dressing that can be efficiently applied in all situations [72]. However, it is possible to develop and to optimize different biocompatible wound dressing materials in terms of their chemical and physical properties, e.g. moisture absorption and permeation capacities, in order to meet most of the needs for a particular wound stage [73].

In general terms and according to their main types and characteristics, the most commonly used wound dressings for diabetic wound healing applications can be easily classified as follows:

(1) Hydrocolloids-these systems are moist wound dressings and usually comprise a backing material (e.g. semi-permeable films, foams or non-woven polyester fibers) and a layer with hydrophilic/colloidal particles that may contain biocompatible gels made of proteins (e.g. collagen, gelatin) or of polysaccharides (e.g. cellulose and its derivatives) $[67,74,75]$. When in contact with wound exudate, these dressings will absorb wound fluids, thus creating a moist environment $[75,76]$. They also have the capacity to be semi-permeable to water and oxygen [74]. However, the application of hydrocolloid dressings in strongly infected wounds has been questioned due to the possible hypoxic and excessively moist environment that could potentiate autolysis of necrotic tissue and therefore increase the risk of infection at the wound site [77,78]. Hydrocolloids are usually applied to granulating and epithelializing wounds and therefore they may be also used for necrotic wounds in order to promote wound debridement [76]. In average, these materials can be maintained on DFUs for more than 
one week [74]. However, there are contradictory studies on whether hydrocolloid-type wound dressings can be used in diabetic foot wounds in the case of superficial wounds, if there are no signs of infection, or if few or moderate wound exudates are present [78].

(2) Hydrogels-these systems are mostly used to maintain highly moist wound environments and are comprised of single or mixed hydrated polymers (i.e. in the form of a gel) presenting at least $20 \%$ of their weight in retained water [73,79]. If the water content is higher than $95 \%$, these materials are usually designated as superabsorbents [77]. Hydrogels may be covalently or non-covalently cross-linked in order to control their swelling capacities and to maintain their conformational structures [67], and they may swell (or shrink) reversibly in aqueous environments of specific $\mathrm{pH}$ and ionic strength values [80]. Like hydrocolloid dressings, hydrogels are capable of promoting the autolytic debridement of necrotic tissues and are usually more efficient at drying wounds with few exudates [79]. Their application in wounds having excess exudate can cause wound maceration and lead to healing problems [81]. A great advantage of hydrogel-type wound dressings is that they can usually be applied/removed without greatly interfering with the wound beds $[73,74]$. In addition, these dressings are flexible, non-antigenic, and permeable to water, oxygen and metabolites [67].

(3) Foams-foam-type dressings were developed as alternatives to hydrocolloid-type dressings for applications in moderate/ high draining wounds [82]. Their capacity to absorb wound fluids is in general dependent on the specific polymeric material employed and on the foam thickness [73]. These dressings are highly absorbent, cushioning, protective and conformable to body surfaces [83]. Moreover, they are easy to manipulate and can be adapted to the required wound size $[74,77]$. Due to their absorbency and protective characteristics, foam-type dressings can be left on the wound for up to seven days [83]. Therefore, foams have been also proposed as potential candidates for DFU treatment [77,82].

(4) Films-these types of wound dressings are normally transparent, durable, conformable, easy to manipulate, adhesive, cheap, semi-permeable to oxygen and water vapor, and often impermeable to liquid and to bacterial contamination $[73,83]$. The main disadvantage of film-type dressings is that they should only be used for wounds with few exudates, namely as protective dressings in superficial pressure wounds and in applications that usually last 4-5 days before the dressing is replaced $[73,74,77]$. However, they may be used directly on the wound or in association with other types of dressings in order to better fix those in the wound bed or to improve their fluid barrier properties $[69,73]$. Film-type dressings have been also developed and employed in DFU treatment [74]. The main characteristics of each of these materials are summarized in Fig. 3.

Different synthetic and natural polymer-based biocompatible materials, as well as their mixtures or combinations and different processing methodologies, have been proposed and assayed both in vitro and in vivo for wound dressing (and DFU) applications [84-86]. Some of these materials are already commercially available and in clinical use $[87,88]$. To supplement and enhance the general wound dressing functions several different strategies have been developed, namely those involving the incorporation of bioactive compounds (e.g. growth factors, peptides, synthetic drugs and/or naturally based compounds/extracts) and of stem cells into dressing matrices in order to prepare medicated dressings [89-92].

\subsection{Polymeric wound dressings for DFU treatment}

Wound healing efficiency depends on several factors such as the wound type and stage, the extent of injury, patient condition, the tissues involved, as well as on the dressing selected, and on the effect of healing enhancers and therapeutic substances (if employed). Wounds can be treated using passive or hydroactive dressings [93]. The first are usually used for acute wounds (as they absorb reasonable amounts of exudates and they can ensure good protection), while the latter are normally used for chronic wounds (as they easily adapt to wounds and are able to maintain a moist environment that can stimulate the healing process) [83]. In both cases, and as already noted, drugs and/or other healing enhancers can be incorporated into the wound dressing polymeric matrices mostly to improve and accelerate healing.

Different constituent polymeric materials, exhibiting distinct chemical, physical and biological properties, may be employed in the preparation of wound dressing systems of different designs, dimensions and shapes, in order to obtain final products offering different final functional properties [72,94]. One of the simplest ways to differentiate those polymeric materials is by considering their origin: synthetic or naturally based polymers and copolymers [95]. Modified polymeric materials (those obtained by chemical

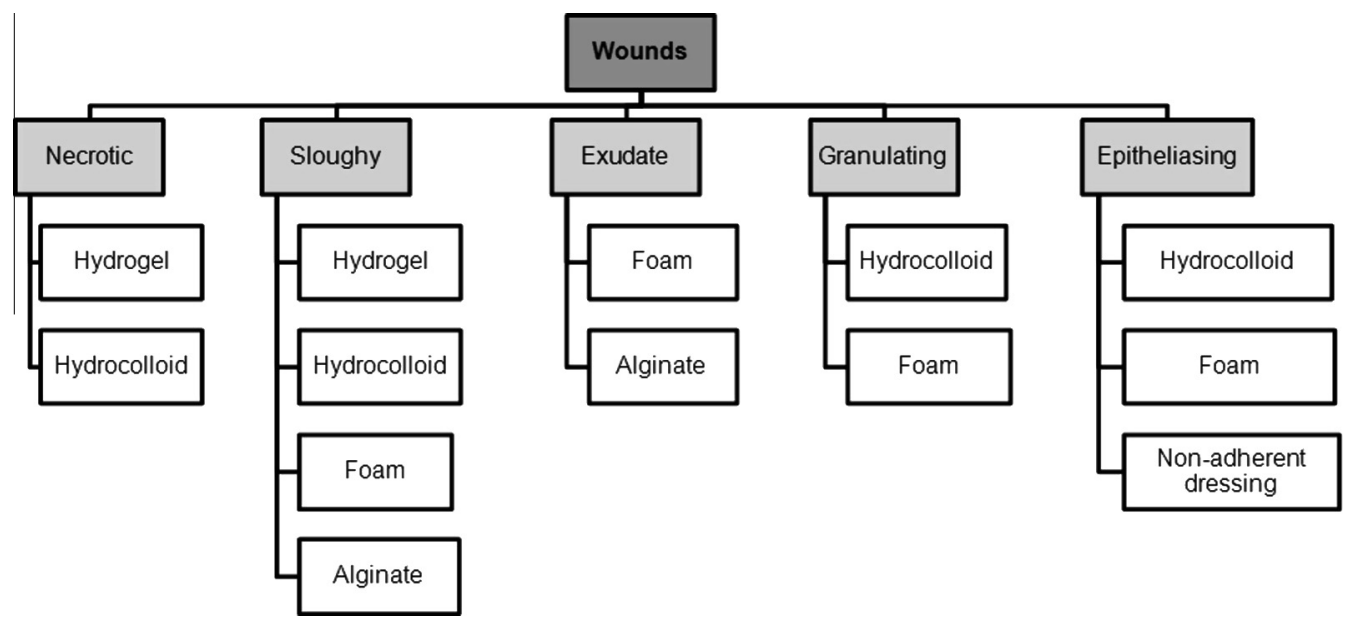

Fig. 3. Classification of the different dressing types usually used in DFU treatment. 
Recently natural and synthetic based dressings studied for DFU application.

\begin{tabular}{|c|c|c|c|c|c|}
\hline Polymers & & Bioactive substance & Models used & Results & References \\
\hline \multirow[t]{4}{*}{$\begin{array}{l}\text { Chitosan and } \\
\text { derivatives }\end{array}$} & Chitosan-crosslinked collagen & $\begin{array}{l}\text { Recombinant human } \\
\text { aFGF }\end{array}$ & STZ diabetic rats & $\begin{array}{l}\text { Accelerated wound healing promoting a faster tissue collagen deposition, } \\
\text { higher TGF- } \beta 1 \text { expression and dermal cell proliferation. }\end{array}$ & $\begin{array}{l}\text { Wang et al, } 2008 \\
{[284]}\end{array}$ \\
\hline & $\begin{array}{l}\text { Chitosan with different degrees of } \\
\text { deacetylation }\end{array}$ & $\begin{array}{l}\text { Acetylglucosamine } \\
\text { oligomers }\end{array}$ & Human diabetic & $\begin{array}{l}\text { Decreased wound size and stimulated angiogenesis and reepithelialization } \\
\text { after seven days. }\end{array}$ & $\begin{array}{l}\text { Ben-shalom et al, } \\
2009[285]\end{array}$ \\
\hline & $\begin{array}{l}\text { Thiolated chitosan-oxidized dextran } \\
\text { hydrogel }\end{array}$ & - & STZ diabetic mice & $\begin{array}{l}\text { Showed to be non-cytotoxic, resistant to degradation and capable of } \\
\text { stimulate tissue regeneration. }\end{array}$ & $\begin{array}{l}\text { Zhang et al, } 2011 \\
\text { [286] }\end{array}$ \\
\hline & $\begin{array}{l}\text { Chitosan, alginate, and poly }(\gamma \text {-glutamic } \\
\text { acid) hydrogel }\end{array}$ & - & STZ diabetic rats & $\begin{array}{l}\text { Enhanced wound healing. Stimulated collagen deposition, hydroxyproline } \\
\text { levels and promoted skin epithelialization. Showed antibacterial properties. }\end{array}$ & Lee et al, 2012 [85] \\
\hline \multirow[t]{7}{*}{$\begin{array}{l}\text { Hyaluronic acid } \\
\text { and derivatives }\end{array}$} & HA benzyl ester films & $\begin{array}{l}\text { Autologous human } \\
\text { keratinocytes }\end{array}$ & $\begin{array}{l}\text { Human patients with non } \\
\text { healing DFU }\end{array}$ & Induced healing of $79 \%$ of DFUs between 7 and 64 days. & $\begin{array}{l}\text { Lobmann et al, } \\
2003[287]\end{array}$ \\
\hline & Poly- $N$-acetyl glucosamine (pGlcNAc) & - & $\mathrm{db} / \mathrm{db}$ diabetic mice & $\begin{array}{l}\text { Wounds dressed reached } 90 \% \text { closure in } 16.6 \text { days, } 9 \text { days faster than } \\
\text { untreated wounds. Higher levels of proliferation and vascularization were } \\
\text { observed in granulation tissue. }\end{array}$ & $\begin{array}{l}\text { Scherer et al, } 2009 \\
{[288]}\end{array}$ \\
\hline & High molecular weight sodium hyaluronate & $\begin{array}{l}\text { Iodine complex- } \\
\text { Hyiodine }\end{array}$ & Human patients with DFUs & Reduced significantly the size of diabetic ulcers. & $\begin{array}{l}\text { Sobotka et al, } 2007 \\
\text { [289] }\end{array}$ \\
\hline & pGlcNAc membrane & - & $\mathrm{db} / \mathrm{db}$ diabetic mice & $\begin{array}{l}\text { Accelerated wound closure mainly by reepithelialization and increased } \\
\text { keratinocyte migration, granulation tissue formation, cell proliferation, and } \\
\text { vascularization. Up-regulated levels of VEGF, UPAR and MMP3, MMP9. }\end{array}$ & $\begin{array}{l}\text { Pietramaggiori } \\
\text { et al, } 2008[290]\end{array}$ \\
\hline & High molecular weight HA gel & - & STZ diabetic rats & $\begin{array}{l}\text { Reduced wound size and increased the number of macrophages, fibroblast } \\
\text { migration, collagen regeneration and epithelization of the wounds. }\end{array}$ & $\begin{array}{l}\text { Bayaty et al, } 2010 \\
{[291]}\end{array}$ \\
\hline & $\begin{array}{l}\text { Cross-linked high and low molecular weight } \\
\text { HA foam }\end{array}$ & Arginine and EGF & STZ diabetic rats & $\begin{array}{l}\text { Significantly decreased wound size and increased the epithelization. In } \\
\text { addition, enhanced the early-stage inflammation. }\end{array}$ & $\begin{array}{l}\text { Matsumoto and } \\
\text { Kuroyanagi, } 2010 \\
\text { [89] }\end{array}$ \\
\hline & HA gel (Vulcamin) & $\begin{array}{l}\text { Mixture of amino } \\
\text { acids }\end{array}$ & $\begin{array}{l}\text { Human patients with } \\
\text { neuropathic ulcers }\end{array}$ & $\begin{array}{l}\text { After } 3 \text { month, the ulcer area and the number of infective complications } \\
\text { were clearly decreased. }\end{array}$ & $\begin{array}{l}\text { Abbruzzese et al, } \\
2009[292]\end{array}$ \\
\hline \multirow[t]{6}{*}{$\begin{array}{l}\text { Cellulose and } \\
\text { derivatives }\end{array}$} & Cellulose dressing & Silver nanoparticles & Human patients with DFUs & $\begin{array}{l}\text { Decreased the activity of Escherichia coli and of Staphylococcus aureus } \\
\text { bacteria by } 99.99 \% \text { in wounds. }\end{array}$ & $\begin{array}{l}\text { Jung et al, } 2009 \\
\text { [149] }\end{array}$ \\
\hline & $\begin{array}{l}\text { Collagen/oxidized regenerated cellulose } \\
\text { foam }\end{array}$ & - & $\begin{array}{l}\text { Human patients with } \\
\text { neuropathic DFUs }\end{array}$ & Application in neuropathic DFUs during 6 weeks stimulated wound healing. & $\begin{array}{l}\text { Lazaro-Martinez } \\
\text { et al, } 2010[293]\end{array}$ \\
\hline & Microbial-derived celullose hydrogel & $\begin{array}{l}\text { Polyhexamethylase } \\
\text { biguanide (PHMB) }\end{array}$ & $\begin{array}{l}\text { Human patients with non- } \\
\text { healing ulcers }\end{array}$ & $\begin{array}{l}\text { Inhibit the proliferation of bacteria, provided an optimal moist healing } \\
\text { environment through the absorption of excess fluid from exudating } \\
\text { wounds. Remove necrosis and hyper granulation tissue to normal levels. } \\
\text { Improvement in healing process was verified. }\end{array}$ & $\begin{array}{l}\text { Serafica et al, } 2010 \\
{[150]}\end{array}$ \\
\hline & $\begin{array}{l}\text { Collagen/oxidized regenerated cellulose } \\
\text { foam }\end{array}$ & - & $\begin{array}{l}\text { Human patients with non- } \\
\text { healing DFUs }\end{array}$ & $\begin{array}{l}\text { Significant decrease the expression of proteases, such as elastase, plasmin, } \\
\text { and gelatinase in wound exudates. }\end{array}$ & $\begin{array}{l}\text { Ulrich et al, } 2011 \\
\text { [294] }\end{array}$ \\
\hline & Microbial cellulose & - & $\begin{array}{l}\text { Human patients with non- } \\
\text { infected DFUs }\end{array}$ & $\begin{array}{l}\text { Treated wounds healed after } 32 \text { days which was faster than the } 48 \text { days } \\
\text { necessary to heal control wounds. }\end{array}$ & $\begin{array}{l}\text { Solway et al, } 2011 \\
{[142]}\end{array}$ \\
\hline & Carboxymethyl celulose hydrogel & Chestnut honey & $\mathrm{db} / \mathrm{db}$ mice & $\begin{array}{l}\text { Significant reduction of wound area, an increase of tissue granulation and } \\
\text { an early-induction of HO-1 were verified at the wound site. }\end{array}$ & $\begin{array}{l}\text { Choi et al, } 2012 \\
\text { [295] }\end{array}$ \\
\hline \multirow[t]{2}{*}{ Alginate } & Alginate hydrogel & Phenytoin & Human patients with DFUs & $\begin{array}{l}\text { Eradicated infection, reduced pain and led to } 60 \% \text { of wound closure after } 16 \\
\text { weeks of treatment. }\end{array}$ & $\begin{array}{l}\text { Shaw et al, } 2011 \\
{[296]}\end{array}$ \\
\hline & Alginate gel & Honey & Human patients with DFUs & Satisfactory healing and stimulated tissue reepithelization. & $\begin{array}{l}\text { Molan et al, } 2011 \\
\text { [297] }\end{array}$ \\
\hline
\end{tabular}


Table 2 (continued)

\begin{tabular}{|c|c|c|c|c|c|}
\hline Polymers & & Bioactive substance & Models used & Results & References \\
\hline \multirow[t]{5}{*}{ Collagen/Gelatin } & Gelatin microspheres & bFGF & $\mathrm{db} / \mathrm{db}$ mice & $\begin{array}{l}\text { Reduced infection, accelerated fibroblast proliferation and capillary } \\
\text { formation. }\end{array}$ & $\begin{array}{l}\text { Kawai et al, } 2005 \\
{[185]}\end{array}$ \\
\hline & Colagen dressing & - & Human patients with DFUs & $\begin{array}{l}60 \% \text { of them healed after two weeks of treatment. A decrease of infection by } \\
\text { bacteria and an augment of granulation tissue were also observed. }\end{array}$ & $\begin{array}{l}\text { Singh et al, } 2011 \\
{[181]}\end{array}$ \\
\hline & $\begin{array}{l}\text { Collagen matrix, Integra }{ }^{\circledR} \text { (Integra } \\
\text { LifeSciences Corp., USA) }\end{array}$ & - & $\begin{array}{l}\text { Human patients with DFUs } \\
\text { at high risk of amputation }\end{array}$ & $\begin{array}{l}\text { Salvaged } 46 \% \text { of the limbs, increased the bacterial clearance and created a } \\
\text { bed of granulation tissue. }\end{array}$ & $\begin{array}{l}\text { Iorio et al, } 2011 \\
\text { [298] }\end{array}$ \\
\hline & Collagen matrix & Glucose oxidase & STZ diabetic rats & Increased cellular proliferation and stimulated a faster wound contraction. & $\begin{array}{l}\text { Arul et al, } 2012 \\
{[182]}\end{array}$ \\
\hline & Collagen-gelatin foam & bFGF & $\mathrm{db} / \mathrm{db}$ mice & $\begin{array}{l}\text { Accelerated dermis tissue formation and increased the number of new } \\
\text { capillaries. }\end{array}$ & $\begin{array}{l}\text { Kanda et al, } 2012 \\
{[186]}\end{array}$ \\
\hline \multirow[t]{4}{*}{ Fibrin } & Fibrin scaffold & AdeNOS & alloxan diabetic rabbit & $\begin{array}{l}\text { Enhanced wound healing, eNOS expression, the inflammatory response and } \\
\text { led to a faster rate of re-epithelialisation in an. }\end{array}$ & $\begin{array}{l}\text { Breen et al, } 2008 \\
{[98]}\end{array}$ \\
\hline & $\begin{array}{l}\text { Combined single-donor platelet gel and } \\
\text { fibrin glue }\end{array}$ & - & Human patients with DFUs & Stimulated wound closure. & $\begin{array}{l}\text { Chen et al, } 2010 \\
\text { [188] }\end{array}$ \\
\hline & Leucopatch $^{\circledR}$ (naturally coagulated fibrin) & - & Human patients with DFUs & Wound area decreased significantly by $65 \%$. & $\begin{array}{l}\text { Jorgensen et al, } \\
2011[299]\end{array}$ \\
\hline & Fibrin gel & CD34 ${ }^{+}$cells & STZ-diabetic mice & Stem cells together with fibrin gel enhanced wound healing. & $\begin{array}{l}\text { Pedroso et al, } 2011 \\
{[189]}\end{array}$ \\
\hline Silk fibroin & Fibroin film & Aloe vera extract & STZ diabetic rat & Enhanced wound healing. & $\begin{array}{l}\text { Inpanya et al, } 2012 \\
{[193]}\end{array}$ \\
\hline Dextran & $\begin{array}{l}\text { Dextran-allyl isocyanate-ethylamine/ } \\
\text { polyethylene glycol diacrylate hydrogel }\end{array}$ & - & $\begin{array}{l}\text { Human patients with } \\
\text { chronic wounds }\end{array}$ & $\begin{array}{l}\text { Promoted dermal regeneration, facilitated the early inflammatory cell } \\
\text { infiltration and promoted cell migration into the wounds. }\end{array}$ & $\begin{array}{l}\text { Sun et al, } 2011 \\
\text { [197] }\end{array}$ \\
\hline Elastin & Elastin-like peptides gel & KGF & STZ diabetic mice & Enhanced reepithelialization and granulation tissue. & $\begin{array}{l}\text { Koria et al, } 2011 \\
\text { [199] }\end{array}$ \\
\hline \multirow[t]{2}{*}{ PVA } & PVA aminated hydrogel & NO & $\mathrm{db} / \mathrm{db}$ mice & $\begin{array}{l}\text { Increased collagen production, enhanced the quality of the granulation } \\
\text { tissue and increased the wound strength. }\end{array}$ & $\begin{array}{l}\text { Bohl et al, } 2002 \\
\text { [215] }\end{array}$ \\
\hline & Aminophenyl boronic acid with PVA & Ciprofloxacin & Diabetic human patients & $\begin{array}{l}\text { Promoted an efficient release of anti-bacterial drugs to improve } \\
\text { complications in long term healing wounds. }\end{array}$ & $\begin{array}{l}\text { Manju et al, } 2010 \\
{[216]}\end{array}$ \\
\hline \multirow[t]{4}{*}{ PEG } & PCL-PEG block copolymer & rhEGF & STZ diabetic mice & $\begin{array}{l}\text { Induced faster wound healing with high proliferation and keratinocytic } \\
\text { expression at the wound site. }\end{array}$ & $\begin{array}{l}\text { Choi et al, } 2008 \\
\text { [229] }\end{array}$ \\
\hline & PEG-PCL nanofibers & EGF and bFGF & STZ diabetic mice & $\begin{array}{l}\text { Increased the accumulation of collagen and keratin and reduced scar } \\
\text { formation. }\end{array}$ & $\begin{array}{l}\text { Choi et al, } 2011 \\
\text { [230] }\end{array}$ \\
\hline & PEGylated fibers & rhaFGF & STZ diabetic rats & $\begin{array}{l}\text { Stimulated wound closure, tissue collagen formation and earlier and higher } \\
\text { TGF- } \beta \text { expression. }\end{array}$ & $\begin{array}{l}\text { Huang et al, } 2011 \\
{[227]}\end{array}$ \\
\hline & Poly(ethylene imine) and PEG & plasmid bFGF & STZ diabetic rats & $\begin{array}{l}\text { Significantly increased the wound recovery rate, enhanced collagen } \\
\text { deposition and maturation and complete re-epithelialization. }\end{array}$ & $\begin{array}{l}\text { Yang et al, } 2012 \\
\text { [226] }\end{array}$ \\
\hline PVP & $\begin{array}{l}\text { Poly (vinyl methyl ether co-maleic } \\
\text { anhydride) and PVP }\end{array}$ & NO & STZ diabetic rats & The complex controlled release of NO and accelerated wound closure. & $\begin{array}{l}\text { Li and Lee, } 2010 \\
{[234]}\end{array}$ \\
\hline
\end{tabular}


modification of naturally based polymers) [96] or mixtures/combinations of different polymers and copolymers [97] can also be considered.

For DFU applications, a wide variety of polymeric materials has already proved to enhance healing and some of these are now commercially available $[98,99]$.

Some of the commonly used polymer-based materials used to produce dressings for DFU treatment will be presented hereafter and a brief description of their structure-property relationships are provided in Table 2. Some examples of commercial dressings currently available for this purpose are also described in Table 3.

\subsubsection{DFU dressings based on natural polymers}

Natural polymers can be classified as those obtained from microbial, animal or vegetal sources that are usually of a protein or polysaccharide nature [100]. Although these naturally occurring polymers can closely simulate the original cellular environments and ECMs, and these biomaterials are known to undergo naturally controlled degradation processes, their large heterogeneity and batch-to-batch variations upon their isolation from animal or vegetal tissues are the main limitations for their applications $[101,102]$. Other concerns include the relatively high cost of some of these materials (namely of protein-based materials) and the associated risk of the transmission of infectious diseases due to the allogenic or xenogenic origins of the original materials [101]. Poor stability and mechanical performance also represent drawbacks that may limit their wider application [103]. However, various chemical synthesis and/or processing modifications may be performed in order to overcome some of these disadvantages [84]. Blending these materials with other polymeric materials (including synthetic polymers) is another viable alternative for in this respect [104]. The natural polymers that are being employed in the preparation of wound dressings, and particularly for DFU treatment, will be presented and discussed in the following sections.

3.2.1.1. Chitin, chitosan and derivatives. Chitin is one of the most abundant polysaccharides in nature. It can be found in the exoskeleton of arthropods, of crustacea, of some mollusks and in the cell walls of fungi [105]. Common chitin sources (e.g. shells of shrimps and crabs) are very accessible at low cost, making chitin a commercially attractive biomaterial for various applications $[106,107]$. Chitin is a linear polysaccharide of $N$-acetyl-D-glucosamine (2-acetylamino-2-deoxy-D-glucose) units linked by $\beta$-(1-4) glycosidic bonds [84,108-111]. As chitin is not soluble in aqueous solutions, it is usually converted into chitosan by thermochemical deacetylation in the presence of an alkaline solution [111,112]. Therefore, chitosan is a linear copolymer of D-glucosamine and of $\mathrm{N}$-acetyl-D-glucosamine. The term chitosan is also usually employed to describe a series of chitin derivatives having different degrees of deacetylation (defined in terms of the composition of primary amino groups in the polymer backbone and of their average molecular weights) [112].

The chemical, physical and biological properties of chitosan are directly related to its deacetylation degree and to its molecular weight [113], and chitosan is generally regarded to be biodegradable, biocompatible, non-antigenic, non-toxic, bioadhesive, anti-microbial, bioactive and to have hemostatic effects $[103,105,114]$. It is also easily degraded by chemical hydrolysis as well as by certain human enzymes, namely lysozyme $[109,110]$. In addition, chitosan amino and hydroxyl groups can be easily reacted and chemically modified, thus allowing a high chemical versatility. For example, chitosan may be modified into $\mathrm{N}$-carboxymethyl chitosan [115], $\mathrm{N}$-carboxybutyl chitosan [116,117], $\mathrm{N}$-succinyl chitosan [118], $\mathrm{N}$-acyl chitosan [119], $\mathrm{N}, \mathrm{O}-$ (carboxymethyl) chitosan [120], $\mathrm{N}-\mathrm{N}$-dicarboxymethyl chitosan 
Table 3

Commercial dressings used for DFU treatment.

\begin{tabular}{|c|c|c|c|}
\hline Commercial dressing & Fabricant & Composition & Main characteristics \\
\hline Bionect $^{\circledR}$ & Dara BioScience & $0.2 \%$ of sodium salt of hyaluronic acid & $\begin{array}{l}\text { - Easy to use } \\
\text { - Reduces the incidence of high-grade skin reactions } \\
\text { - Reduces wound severity }\end{array}$ \\
\hline Unite $^{\circledR}$ Biomatrix & $\begin{array}{l}\text { Synovis } \\
\text { Orthopedic and } \\
\text { WoundCare, Inc. }\end{array}$ & Non-reconstituted collagen & $\begin{array}{l}\text { - Collagen dressing helps maintain wound bed in healing phase } \\
\text { - Allows for healthy granulation tissue and wound closure } \\
\text { - Absorbs excess exudate allowing few dressing changes } \\
\text { - Easily conforms to the wound bed } \\
\text { - Strong and durable }\end{array}$ \\
\hline BGC Matrix $^{(B)}$ & $\begin{array}{l}\text { Mölnlycke } \\
\text { Health Care US, } \\
\text { LLC }\end{array}$ & $\begin{array}{l}\text { Collagen and the advanced carbohydrate } \\
\text { beta-glucan }\end{array}$ & $\begin{array}{l}\text { - Protects underlying tissue from external contamination } \\
\text { - Provides structural support for new cell growth } \\
\text { - Adherent, flexible and conformable } \\
\text { - Minimizes protein and water loss } \\
\text { - Collagen aids in hemostasis } \\
\text { - Minimizes pain }\end{array}$ \\
\hline
\end{tabular}

Promogran Prisma ${ }^{\circledR}$ Matrix $\quad$ Systagenix $\quad$ Collagen, ORC and silver-ORC matrix

- In the presence of exudate, the matrix transforms into a biodegradable gel

- Provides protection from infection and optimal healing environment

- Designed to "kick start" the healing process in stalled wounds

- Biodegradable gel is soft and conformable

- Can be used under compression therapy

- Non-toxic and non-irritating

- Easy to use

Dermacol/AgTM

Collagen Matrix

Dressing with Silver

Fibracol ${ }^{\circledR}$ Plus Collagen Wound Dressing with Alginate

Aquacel Hydrofiber ${ }^{\circledR}$ Wound Dressing

Regranex $^{\circledR} \mathrm{Gel}$

\section{MediHoney ${ }^{\circledR}$ \\ Adhesive \\ Honeycolloid \\ Dressing}

Systagenix

DermaRite

Industries methyl- cellulose, ethylenediaminetetraacetic acid (EDTA) and silver chloride

Collagen and calcium alginate fibers wound

Antimicrobial hydrofiber containing carboxymethyl cellulose with ionic silver

Healthpoint Biotherapeutics

rh PDGF-BB incorporated in aqueous sodium carboxymethylcellulose

Derma Sciences, $\quad 80 \%$ active Leptospermum honey with Inc. colloidal alginate

\footnotetext{
MediHoney ${ }^{\circledR}$

Calcium Alginate

Dressing
}

Derma Sciences, Contains 95\% active Leptospermum honey Inc.

- Transforms into a soft gel sheet when in contact with wound exudates

- Maintains a moist wound environment, and creates ideal conditions for healing

- Antimicrobial silver chloride prevents colonization of the dressing

- Easy to use

- Structural support of collagen with gel forming properties of alginates

- Maintains a moist wound environment, and creates ideal conditions for healing

- Adherent, flexible and conformable

- Sterile and soft

- Absorbs wound fluid and creates a soft gel, which maintains a moist wound environment

- Absorbs and retains exudate and harmful components, such as bacteria contained within exudate, directly into its fibers

- Helps reduce the pain and trauma upon dressing removal

- Conforms to the wound surface

- Used on moderately and highly exuding chronic wounds

- Stimulates wound healing processes and aids in creation of granulation tissue

- Only FDA-approved topical agent with platelet-derived growth factor

- Promotes the recruitment and proliferation of chemotactic cells

- Stimulates wound closure

- Easy to use

- Maintains effectiveness even in the presence of wound fluid, blood and tissue

- For wounds with light to moderate amounts of exudates

- Pad will form a gel as it warms up and contacts wound fluid

- Promotes a moisture-balanced environment conducive to wound healing

- Helps wounds that have stalled progress toward healing

- High osmolarity cleanses

- Helps lower overall wound $\mathrm{pH}$

- Non-toxic, natural, safe and low-cost

- As wound fluid enters the dressing, the honey is released while the dressing forms a gel

- Maintains effectiveness even in the presence of wound fluid, blood and tissue

- Promotes a moisture-balanced environment conducive to wound healing

- Highly osmotic and helps to reduce overall wound $\mathrm{pH}$

- For wounds with moderate to heavy amounts of exudates

- Non-toxic, natural, safe and easy to use 
Table 3 (continued)

\begin{tabular}{|c|c|c|c|}
\hline Commercial dressing & Fabricant & Composition & Main characteristics \\
\hline $\begin{array}{l}\text { Algisite } * \\
\quad \text { Calcium Alginate Dressing }\end{array}$ & $\begin{array}{l}\text { Smith \& Nephew, } \\
\text { Inc. }\end{array}$ & Calcium-alginate & $\begin{array}{l}\text { - Forms a gel that absorbs exudate when in contact with wound } \\
\text { - Helps prevent scar formation and promotes wound } \\
\text { contraction } \\
\text { - Allows gas exchange necessary for a healthy wound bed } \\
\text { - Low-adherence reduces trauma at dressing changes } \\
\text { - Conforms to wound contours } \\
\text { - Low fiber shed } \\
\text { - Easy to remove }\end{array}$ \\
\hline Sorbalgon ${ }^{\circledR}$ & $\begin{array}{l}\text { Hartman USA, } \\
\text { Inc. }\end{array}$ & Calcium alginate & $\begin{array}{l}\text { - Forms a hydrophilic gel on contact with wound exudate } \\
\text { - Maintains integrity while dry or wet } \\
\text { - High absorbent } \\
\text { - Easy to remove } \\
\text { - Latex-free }\end{array}$ \\
\hline Kaltostat ${ }^{\circledR}$ Dressing & ConvaTec & Sodium and calcium salts of alginic acid & $\begin{array}{l}\text { - In the presence of exudate or other body fluids containing } \\
\text { sodium ions, the fibers absorb liquid and swell } \\
\text { - Calcium ions present promote the dressing to take on a gel- } \\
\text { like appearance } \\
\text { - Facilitates wound healing providing a favourable micro- } \\
\text { environment } \\
\text { - Easy to use }\end{array}$ \\
\hline $\begin{array}{l}\text { Tegaderm }{ }^{\mathrm{TM}} \text { High Gelling } \\
\text { Alginate Dressing }\end{array}$ & 3 M Health Care & Polyurethane dressing containing alginate & $\begin{array}{l}\text { - Forms a gel-like consistency as it absorbs exudate to provide a } \\
\text { moist healing environment } \\
\text { - Completely gels with saturation for easy removal from fragile } \\
\text { tissue by gentle irrigation } \\
\text { - Easily irrigated from the wound bed when saturated } \\
\text { - Highly absorbent dressings and conformable }\end{array}$ \\
\hline $\begin{array}{l}\text { GranuDerm }^{\mathrm{TM}} \\
\text { Sentry }^{\mathrm{TM}}\end{array}$ & $\begin{array}{l}\text { Acute Care } \\
\text { Solutions, LLC }\end{array}$ & Alginate hydrocolloid with polyurethane & $\begin{array}{l}\text { - Breathable film membrane surrounds the wound site } \\
\text { - Promotes wound repair } \\
\text { - Visually signals dressing changes } \\
\text { - Water, dirt and germ proof } \\
\text { - Reduces dressing changes } \\
\text { - Extended wear time } \\
\text { - Prohibits leakage }\end{array}$ \\
\hline Biatain ${ }^{\circledR}$ Heel Foam Dressing & Coloplast Corp. & 3-D non-adhesive foam of polyurethane & $\begin{array}{l}\text { - Foam absorbs and retains wound exudate to control moisture } \\
\text { balance in wound } \\
\text { - Absorbs low-to-high wound exudate levels and protects the } \\
\text { heel } \\
\text { - Decrease wound are and prevents skin maceration } \\
\text { - Soft, beveled edges makes dressing more comfortable for } \\
\text { patient } \\
\text { - Longer wear time for fewer dressing changes } \\
\text { - Low risk of leakage or maceration } \\
\text { - Safe and effective }\end{array}$ \\
\hline $\begin{array}{l}\text { Biatain Ibu Foam Dressing Non- } \\
\text { adhesive }\end{array}$ & Coloplast Corp. & $\begin{array}{l}\text { Combination of polyurethane-foam, } \\
\text { polyurethane film, polyethylene and } \\
\text { ibuprofen }\end{array}$ & $\begin{array}{l}\text { - Combines moist wound healing with an active pain reliever } \\
\text { - Releases ibuprofen evenly into the wound } \\
\text { - Helps to ease pain from the wound during wear and when } \\
\text { changing the dressing } \\
\text { - Promotes wound repair } \\
\text { - Easy to use }\end{array}$ \\
\hline MANUKAhd ${ }^{\circledR}$ & $\begin{array}{l}\text { ManukaMed } \\
\text { USA, Inc. }\end{array}$ & $\begin{array}{l}\text { Polyurethane foam and film in backing } \\
\text { and an absorbent dressing pad of } \\
\text { polyacrylate polymers impregnated with } \\
\text { ManukaMed }^{\circledR} \text { honey }\end{array}$ & $\begin{array}{l}\text { - } 100 \% \text { active medical grade Manuka }{ }^{\circledR} \text { honey } \\
\text { - Gentle on wounds promoting wound healing } \\
\text { - Forms gels in contact with exudate } \\
\text { - Fluid permeable and dry-touch }\end{array}$ \\
\hline DuoDERM $^{\circledR}$ CGF $^{\circledR}$ & ConvaTec & Polyurethane foam & $\begin{array}{l}\text { - Promotes granulation and facilitates autolytic debridement } \\
\text { - Can be easily and gently molded into place } \\
\text { - Use on lightly to moderately exuding acute and chronic } \\
\text { wounds } \\
\text { - Minimize skin trauma and disruption of healing } \\
\text { - Can be worn for up to } 7 \text { days } \\
\text { - Allows observation of the healing process due to its } \\
\text { transparency }\end{array}$ \\
\hline $\begin{array}{l}\text { SOLOSITE }^{\circledR} \text { Conformable Wound } \\
\text { Gel Dressing }\end{array}$ & $\begin{array}{l}\text { Smith \& Nephew, } \\
\text { Inc. }\end{array}$ & Polyurethane and polyethylene hydrogel & $\begin{array}{l}\text { - Creates a moist wound healing environment } \\
\text { - Keeps gel in intimate contact with wound surface } \\
\text { - Absorbs excess exudate allowing few dressing changes } \\
\text { - Non-cytotoxic and non-sensitizing }\end{array}$ \\
\hline $\begin{array}{l}\text { Silverlon }{ }^{\circledR} \text { Island Wound } \\
\text { Dressing }\end{array}$ & $\begin{array}{l}\text { Argentum } \\
\text { Medical, LLC }\end{array}$ & Polyurethane film containing silver & $\begin{array}{l}\text { - Non-adherent wound contact layer } \\
\text { - Provides effective protection against microbial contamination } \\
\text { - Permits passage of wound exudate } \\
\text { - Stimulates wound repair } \\
\text { - Easy to apply }\end{array}$ \\
\hline
\end{tabular}


Table 3 (continued)

\begin{tabular}{|c|c|c|c|}
\hline Commercial dressing & Fabricant & Composition & Main characteristics \\
\hline Allevyn & $\begin{array}{l}\text { Smith \& Nephew, } \\
\text { Inc. }\end{array}$ & $\begin{array}{l}\text { polyurethane films combined with } \\
\text { polyurethane foam containing } 5 \% \text { silver } \\
\text { sulphadiazine. }\end{array}$ & $\begin{array}{l}\text { - Minimizes pain to the patient and trauma to the wound at } \\
\text { dressing change } \\
\text { - Rapid and sustained ( } 7 \text { days) antibacterial action } \\
\text { - Absorbs, retains and transpires exudate to provide enhanced } \\
\text { fluid management } \\
\text { - Provides a moist wound environment for the promotion of } \\
\text { faster closure } \\
\text { - Stays in place for up to } 7 \text { days }\end{array}$ \\
\hline Meliplex Ag & $\begin{array}{l}\text { Molnlycke Heath } \\
\text { Care }\end{array}$ & $\begin{array}{l}\text { Polyurethane foam containing a silver } \\
\text { compound (silver sulphate) }\end{array}$ & $\begin{array}{l}\text { - Vapor-permeable } \\
\text { - Waterproof film to absorb exudate } \\
\text { - Maintains a moist wound environment }\end{array}$ \\
\hline Ligasano & Ligasano & Honeycomb-polyurethane foam & $\begin{array}{l}\text { - Economic and manageable } \\
\text { - Absorbs high amounts of exudate without dehydrating the } \\
\text { wound bed } \\
\text { - Creates a moist and warm wound environment } \\
\text { - Antiseptic and cleans the wound with no sticking to the } \\
\text { wound } \\
\text { - Stimulates local blood circulation in the wound }\end{array}$ \\
\hline
\end{tabular}

[121], N-carboxyethyl chitosan [122], O-succinyl chitosan [123], Ocarboxymethyl chitosan [124], 5-methylpyrrolidinone [125] and more. The conditions employed for amino group chemical modification may interfere with the final degree of deacetylation and therefore with the cationic nature of the obtained materials. Chitosan exhibits a $\mathrm{pH}$-sensitive behavior being a weak poly-base (due to the large number of amino groups). Chitosan easily dissolves at relatively low $\mathrm{pH}$ values (while it is insoluble at higher $\mathrm{pH}$ values, usually above $\mathrm{pH}$ 6.0) and its $\mathrm{pH}$-sensitive swelling mechanism involves the protonation of the amine groups under these low pH conditions $[105,126]$. Chitosan is also soluble in weak organic acids, interacting with negatively charged molecules, which may facilitate its processing and further integration into particles, membranes, fibers or sponges $[107,127]$. This property has led chitosan and its derivatives (alone or combined/conjugated with other polymeric materials) to be widely studied as delivery matrices for a number of pharmaceutical applications [96,105,128,129]. At acidic $\mathrm{pH}$, chitosan is positively charged and therefore it is more susceptible to interaction with negatively charged molecules such as proteins, anionic polysaccharides and nucleic acids, which are usually present in skin $[67,130]$.

In addition to the fact that chitosan-based materials usually exhibit a positive charge (at typical wound $\mathrm{pH}$ values), film-forming capacities, mild gelation characteristics and strong wound tissue adhesive properties, chitosan and its derivatives were also found to enhance blood coagulation and to accelerate wound healing $[84,109]$. Therefore, these materials clearly present several properties that can potentially permit their use as advantageous and efficient wound dressings. In particular, chitosan films of low deacetylation degree have already proved to be efficient for dressing superficial wounds [111]. Other works also indicated that these biomaterials enhance the inflammatory functions of polymorphonuclear leukocytes, macrophages and neutrophils, promoting tissue granulation to an appropriate inflammatory response [131]. Moreover, chitosan may stimulate the proliferation of fibroblasts, angiogenesis, synthesis and a regular deposition of collagen fibers that leads to improved tissue organization [84,109,132].

Chitosan can be also complexed/cross-linked with other charged or non-charged polymers and/or cross-linking agents to change/enhance its physical/chemical/mechanical properties. Through this approach it is possible to optimize and/or to design chitosan-based dressings with improved healing characteristics that include enhanced adherent and anti-bacterial capacity, increased exudate absorption capacity, stimulation of angiogenesis and re-epithelialization of skin tissue and collagen deposition, sustained delivery of growth factors, etc. The main achievements recently obtained with chitosan-based dressings for wound healing (with the focus on DFU) treatments are summarized in Table 2.

3.2.1.2. Hyaluronic acid and other glycosaminoglycans. Hyaluronic acid (HA) is a natural polysaccharide, namely a non-sulfated glycosaminoglycan (GAG), which is a major component of the ECM of the connective tissues of certain mammals such as cartilage, eye vitreous humor, umbilical cord and synovial fluid [67,101]. HA is also referred to as hyaluronan due to the fact that it usually exists in vivo as a polyanion and not in the protonated acidic form [133]. It is a linear polysaccharide of alternating disaccharide units of $\alpha$-1,4-D-glucuronic acid and $\beta$-1,3-N-acetyl-D-glucosamine, linked by $\beta(1 \rightarrow 3)$ glycosidic bonds [126]. HA is usually extracted from the umbilical cord, vitreous humor, synovial fluid or from rooster combs [134]. When extracted from the host body, HA is non-allergenic and biocompatible $[135,136]$. However, it is already easily produced on a large scale and in a controllable and reproducible way by microbial fermentation [133]. HA is water soluble up to certain concentrations and can produce highly viscous solutions with unique viscoelastic properties. It can form three-dimensional structures in ex vivo aqueous solutions through hydrogen bonding [133].

HA presents many important physiological functions such as structural and space-filling properties, lubrication, as well as tissue and ECM water sorption and retention abilities [135,137]. HA is also an interesting biomaterial for wound healing applications since it is known to promote mesenchymal and epithelial cell migration and differentiation, thus enhancing collagen deposition and angiogenesis [133,136,138].

HA's chemical and physical properties, namely its mechanical properties and degradation profiles, are strongly dependent on its molecular weight. Native high molecular weight HA has important structural properties, whereas its degradation products may stimulate endothelial cell proliferation and migration, modulate the inflammatory processes and promote angiogenesis during the different wound healing stages $[137,139,140]$. A large number of studies involving the use of HA in the context of DFU, processed as foams or gels, with or without bioactive substances, have been reported and these are summarized in Table 2.

3.2.1.3. Cellulose and its derivatives. Cellulose is the primary structural component of plant cell walls and is the most abundant organic polymer on Earth. Therefore, it is a renewable biomaterial, readily available at low cost [101]. Furthermore, it can also be eas- 
ily converted into several potentially advantageous derivatives. Cellulose is a linear polymer constituted by $\beta-1,4$ linked D-glucose units which are joined to form cellobiose repeating units [141]. Cellulose glucan chains are parallel and are packed side-by-side, forming microfibrils, stabilizing the structure but minimizing its flexibility. The degrees of polymerization and the molecular organization of its chains are the main characteristics that affect the chemical and physical properties of cellulose and thus its processing methods and applicability [142]. This highly cohesive hydrogen-bonded structure provides cellulose fibers of great stability, rigidity and tensile strength and makes them water insoluble (despite their hydrophilic character). Cellulose and its derivatives are slightly degradable by several bacteria and fungi present in air, water and soil, which leads to a decrease in its mechanical strength and to an improvement in its water solubility [141,143]. In addition, cellulose-based materials are considered biocompatible due to their reduced inflammatory response to foreign bodies $[143,144]$. Moreover, resorption of cellulose in tissues does not occur since cells are not able to synthesize cellulases [144].

Some cellulose ether derivatives such as methyl cellulose, hydroxypropyl cellulose, hydroxyethyl cellulose, hydroxyethyl methyl cellulose, hydroxypropyl methyl cellulose and carboxymethyl cellulose are cold and/or hot water-soluble up to some concentrations and present other interesting properties such as organic-solvent solubility, thermoplastic behavior and biosurface activity. Cellulose ester derivatives, such as cellulose acetate, cellulose triacetate and cellulose sulfate, are also fiber- and film-forming materials [145]. Moreover, their molecular weights can be varied, and therefore their aqueous viscosities and gelation properties can be tuned $[143,146]$. These features allow their use in several pharmaceutical formulations and for various biomedical purposes.

Microbial (or bacterial) cellulose (MC) is different from plantorigin cellulose. It is synthesized by various bacteria and has already proved to present great potential for wound healing applications $[147,148]$. Its high mechanical strength, crystallinity and high capacity to retain water mostly arise from its unique nanofibrillar structure [143,147].

Some studies have demonstrated that cellulose stimulates wound healing through the release and maintenance of therapeutic levels of a number of growth factors (i.e. PDGF, epidermal growth factor (EGF) and FGF) at the wound site and by promoting dermal fibroblast migration and proliferation and inhibiting bacterial proliferation in wounds [149-151]. In this last case a significant improvement was observed by loading the dressing material with antimicrobial agents such as polyhexamethylase biguanide (PHMB) or silver. The biocompatibility of cellulose-based materials has been achieved by combining cellulose with other polymers such as collagen. An example of a commercial cellulose-based dressing is Aquacel ${ }^{\circledR}$ Hydrofiber WoundDressing (ConvaTec, USA), which is an antimicrobial carboxymethyl derivative of cellulose that can absorb wound fluids and create a gel to maintain a moist wound environment for proper wound healing. These and other achievements obtained after the use of cellulose-based dressings in the context of DFU healing are summarized in Table 2.

3.2.1.4. Alginate. Alginate (or alginic acid) is one of the most studied and applied polysaccharides in tissue engineering and drug delivery applications. It is abundant in nature since it is a structural component of marine brown algae (Laminaria hyperborean, Ascophyllum nodosum and Macrocystis pyrifera) and as capsular polysaccharides in some soil bacteria [101]. It is constituted by $\beta$-D-mannuronate (M-residues) and $\alpha$-L-guluronate (G-residues) residues covalently linked in different alternating or random sequences/blocks $[101,141,152]$.
Alginates can form reversible hydrogels through the interaction with divalent cations, such as $\mathrm{Ca}^{2+}, \mathrm{Mg}^{2+}, \mathrm{Ba}^{2+}$ or $\mathrm{Mn}^{2+}$, that can cross-link $\mathrm{G}$-residues of adjacent alginate chains by means of ionic interactions [152]. Despite other applications, these easy crosslinking and processing strategies allow their wide use as threedimensional supports for cell transplantation, as well as wound dressing biomaterials. Moreover, alginate has high biocompatibility, low toxicity and good mucoadhesive properties [101,141,153]. Alginate-based biomaterials are also pH sensitive and the release of bioactive species from these materials at low $\mathrm{pH}$ conditions is significantly reduced. Therefore, this feature could be advantageous for the development of a delivery system intended for near-neutral $\mathrm{pH}$ conditions [152].

However, alginate-based hydrogels may present unpredictable and uncontrollable degradation and dissolution profiles after loss of the divalent cation cross-linkers [153]. To overcome this issue, covalent/ionic cross-linking can be employed with other biopolymers such as gelatin [154], heparin [155], polyvinyl alcohol [156] and chitosan [157]. The other main disadvantage of alginate-based materials is their inability to undergo efficient and rapid enzymatic degradation in mammals. In addition, alginates are very hydrophilic, which hinders its interactions with skin proteins [152].

Calcium alginate-based dressings are recognized to have the capacity to efficiently absorb wound exudates, hence facilitating debridement and accelerating wound healing in DFU $[82,158,159]$. Alginate-based dressings have also been combined with growth factors such as stromal derived factor-1 (SDF-1) or drugs such as phenytoin, ibuprofen or clindamycin to improve DFU treatment. Commercial products such as Medihoney (Derma Sciences Inc., Canada) which is an alginate hydrocolloid wound dressing loaded with a minimum of $70 \%$ of active Leptospermum honey or Algisite M Calcium Alginate Dressing (Smith and Nephew Inc., Australia) are alginate-based dressings indicated for DFU treatment. These and other examples of the application of alginate dressings for DFU wound healing are summarized in Table 2.

3.2.1.5. Collagen and gelatin. Collagen is the most abundant protein of the ECMs naturally present in human tissues (e.g. skin, bone, cartilage, tendon and ligaments). It represents $25 \%$ of the total protein body content $[80,102,160,161]$, providing strength and integrity to tissue matrices [162]. In addition, collagen can also interact with cells and help essential cell signaling that will regulate cell anchorage, migration, proliferation, differentiation and survival [101,120,162].

Twenty-seven types of collagens have already been identified, with types I-IV being the most common. Type I collagen is the most abundant protein present in mammals and is the most studied protein for biomedical applications [101,141].

Collagen degrades enzymatically within the body, mostly via collagenases, gelatinases and metalloproteinases [163]. In general terms, collagens are rod-type proteins with typical molecular weights around $300000 \mathrm{~g} \mathrm{~mol}^{-1}$ that also present high mechanical strength and good biocompatibility (although they may present some antigenicity) [101,164]. Collagen can form stable fibers and its mechanical, degradation and water-uptake properties can be further enhanced by chemical cross-linking (using glutaraldehyde [165], genipin [166], carboiimide [167], hexamethylene diisocyanate [168]), by physical cross-linking (using freeze-drying) [169] or by binding with other protein/polymers $[170,171]$. Low inflammatory and cytotoxic responses and biodegradability are other attractive properties of collagen [102].

As a result, and since collagen is one of the major components of human ECMs, it is usually considered as an ideal biomaterial for tissue engineering and for wound dressing applications. Collagen is usually isolated from animal tissues, a source that raises some concerns [163,164]. However, enzymatic purification techniques 
(to eliminate those immunogenic telopeptides that induce foreign body response) may be employed [172]. Alternatively, the use of recombinant and non-recombinant human collagens can be envisaged but their production currently incurs high costs [164]. Collagen is also difficult to process and its degradation rate cannot easily be controlled $[101,163]$. For example, collagen degradability depends on cell three-dimensional structure penetration (which causes contraction, inner pressure increase, fluid restrictions and makes collagen less swellable and degradable), and, in addition, collagen is also degradable by other non-specific proteinases [101]. Finally, collagen sterilization may be also an issue as the sterilization methods currently employed may promote chemical and physical modifications of the collagen structure [163].

Gelatin is a collagen derivative which is commonly used as an hydrogel for pharmaceutical and biomedical applications mostly because of its straightforward processability and good biodegradability/biocompatibility in physiological environments [101,173]. Moreover, gelatin has relatively low antigenicity because it is a denatured protein material (in contrast to collagen, which is known to present some antigenicity due to its unaltered animal origin) [102].

Gelatin can be obtained by the acidic or alkaline processing (denaturation) of collagen [174]. Consequently, two different types of gelatin can be obtained according to the methods employed for collagen pretreatment. These different $\mathrm{pH}$ pretreatments will also affect the isoelectric points of the gelatin biomaterials obtained, and manufacturers can now provide gelatin with a wide range of isoelectric point values, from alkaline gelatin (with an isoelectric point of 9.0) down to acidic gelatin (with an isoelectric point of 5.0) [101]. This is an important feature as it allows the complexation of gelatin with either positively or negatively charged biomolecules. Basic gelatin is preferable as the carrier matrix for an acidic bioactive molecule, while acidic gelatin should be employed for the release of basic bioactive substances [175].

In general terms, the release of these substances is controlled by the enzymatic degradation of the gelatin-based materials involved. Therefore, and similar to collagen, the degradation profiles (and the mechanical properties) of gelatin-based hydrogels may be adjusted by controlling the degree of cross-linking (which will also control the hydrogel water content) [176]. As for collagen cross-linking, it can be performed by chemical methods (e.g. using water-soluble carbodiimides [177], glutaraldehyde [178] or genipin [179]) or through physical cross-linking (by thermal treatment, by the formation polyion complexes with other polymers or by blending with other gelating polymers) $[154,180]$.

Due to all the above-mentioned characteristics, collagen is frequently used to prepare wound dressing materials in diverse forms that include gels, pads, particles, pastes, powders, sheets or solutions. A large number of commercial collagen-based dressings is already available and some are specifically indicated for partial- and full-thickness pressure, venous, vascular and diabetic ulcers as is the case of BCG $^{\circledR}$, BIOSTEP $^{\circledR}$, Catrix $^{\circledR}$, CollaSorb ${ }^{\circledR}$ and PROMOGRAN PRISMA ${ }^{\circledR}$ Matrix (Table 3).

As reported in Table 2, recent studies have proved the efficacy of collagen and gelatin dressings for decreasing infection by bacteria and favoring granular tissue formation, stimulating faster wound healing in DFU patients [181-184]. Different approaches tested so far include the incorporation of glucose oxidase in a collagen matrix in order to achieve the sustained delivery of reactive oxygen species (ROS), natural compounds (such as polyphenols), growth factors (such as bFGF), antibiotics (such as doxycycline and levofloxacin) and ionic silver as antimicrobial agent $[182,185,186]$.

3.2.1.6. Fibrin. Fibrin is a protein that is produced from fibrinogen and hence can be autologously harvested from patients. Therefore, it may provide immunocompatible polymeric carriers for the delivery of bioactive molecules and/or cells in various biomedical applications [101,102]. Polymerized fibrin is a major component of blood clots and is recognized to play an important role in the subsequent wound healing response [102,187]. On the other hand, fibrin contains some specific domains that may improve cell binding, and therefore it has also been studied as an advantageous biomaterial for cell adhesion, spreading, migration, proliferation and tubule formation $[101,153,187]$. Due to these characteristics, fibrin-based biomaterials (including modified/cross-linked fibrin and fibrin composites) may also be applied for drug and cell delivery for tissue engineering applications. The most widely used forms of fibrin scaffolds are fibrin hydrogels and fibrin glue. Fibrin hydrogels are known to promote angiogenesis and to enhance neurite extension. A major drawback is that fibrin hydrogels have low mechanical stiffness, and rapid degradation may occur before the proper formation of tissue-engineered structures [187]. Finally, fibrin glues are biological adhesives commonly used in surgical procedures (mostly due to their hemostatic, chemotactic and mitogenic properties) [101]. These glues have also been described to facilitate the fixation of skin grafts and to limit the risk of infection in chronic wounds [188]. Fibrin gels can be obtained by the enzymatic cross-linking of fibrinogen with thrombin. The final structure of fibrin gels will thus depend on the concentration of thrombin and fibrinogen, on local $\mathrm{pH}$ and ionic strength, as well as on the local calcium concentration [189]. Wound healing improvements were obtained after application of fibrin gels incorporating hematopoietic stem cells $\left(\mathrm{CD} 34^{+}\right), \mathrm{CD} 34^{+}$-derived endothelial cells, or both. Since pluripotent stem cells are able to differentiate into fibroblasts, keratinocytes and endothelial cells, they may also play an important role during the wound healing process [189]. Bone marrow-derived stem cell transplantation can also be used for the healing of chronic lower extremity wounds. Hassan et al. [190] topically applied a concentrated solution of bone marrow stem cells combined with platelets and fibrin glue in a collagen dressing. After 4 weeks of treatment, diabetic ulcers were totally closed in three patients and significantly reduced in another five patients. Other approaches to enhance the effect of fibrin gels to improve healing include the use of enzymes to produce and deliver nitric oxide (NO) which enhances the inflammatory response and faster re-epithelialization, and the use of platelets that work as powerful mitogenic and chemostatic factors. The healing effect of Vivostat, a platelet-rich fibrin treatment for DFUs, has been studied in a clinical trial [191]. The ulcers of patients were treated from weeks 1 to 6 with Vivostat platelet-rich fibrin. The results showed that ulcers were completely healed after 12 weeks. These achievements are summarized in Table 2.

3.2.1.7. Silk fibroin. Fibroin protein can be isolated from the silkworm (Bombyx mori or Antheraea mylitta). It is receiving attention for biomedical applications due to its biocompatibility, hemocompatibility, slow degradability, water vapor and gas permeability besides its widespread versatility [192,193]. Silk fibers are composed of a fibrous protein (fibroin) core and a glue protein (sericin) surrounding it. Even though fibroin does not promote immunological responses, silk sericin protein may have the opposite effect [194]. In addition, silk fibroin is able to support epidermal cells and fibroblast attachment, spreading and proliferation, thus promoting wound healing [101]. Fibroin films loaded with aloe gel extract were recently applied in the treatment of streptozotocin-induced diabetic rats [193]. Compared to aloe-free fibroin film, the blended film enhanced the attachment and the proliferation of skin fibroblasts. Moreover the wounds in diabetic rats presented a smaller area 7 days after wounding (when compared to untreated diabetic wounds) and fibroblast distribution and collagen fiber organization similar to wounds in normal rats. These results show that acceler- 
ated wound healing can be obtained by using blended fibroin/aloe gel films which may be applied in the treatment of diabetic nonhealing skin ulcers.

3.2.1.8. Dextran. Dextran is constituted by $\alpha(1 \rightarrow 6)$-linked D-glucose residues with some degree of branching via $\alpha(1 \rightarrow 3)$ linkages, and is obtained from various bacterial strains via the action of dextransucrase [101,141]. Dextran is hydrophilic, highly soluble in water, inert in biological systems and easily functionalized through its reactive hydroxyl groups [195,196]. Dextran is available in a wide range of molecular weights, as well as in the form of several dextran derivatives. It is biodegradable, biocompatible, resists protein adsorption and does not affect cell viability. Therefore it is a good polymer for medical applications such as bone, dermal and subcutaneous healing and for drug delivery $[101,196]$. It facilitates inflammatory cell infiltration and promotes angiogenic cell migration into the wounds [197]. Diabetic patients have been treated with dextranomer, a dextran polymer which is applied locally to the ulcer or the infected wound [198]. Wounds were covered with a thick layer of dextranomer and further covered with a dry absorbent gauze and non-occlusive bandage dressing. Of the 15 lesions treated, 12 healed completely (for an average period of 8 days) showing the potential of dextran-based materials to treat DFUs. This study showed that the effect of dextranomer on the infected wound was rapid, leading to a remarkable decrease of the inflammatory reaction around the wound during the first day and the formation of healthy granulation tissue within a few days without pain, edema and tenderness. According to this and other previous studies it was proposed that the enhanced effect of dextranomer is due to its capacity to cleanse the lesion by absorbing the wound exudate, protein degradation products, prostaglandins, bacteria and other contaminants, reducing inflammation and improving healing.

3.2.1.9. Elastin. Elastin is an insoluble ECM protein and a major constituent of skin elastic fibers [199,200]. Elastin is highly insoluble and difficult to process into new biomaterials. Nevertheless, its soluble forms, including tropoelastin (a soluble precursor form of elastin), $\alpha$-elastin (an oxalic acid derivative of elastin) and elastin-like polypeptides have much broader applications as elastinbased biomaterials [200,201]. Elastin can also be cross-linked by chemical (e.g. using aldehydes and epoxy groups) [202,203], enzymatic [204] and physical processes [205]. These strategies allow an efficient binding to amino acids side chains, low antigenicity and improved mechanical strength [201]. Soluble elastin-based biomaterials promote a natural elasticity, favorable cellular interactions and enhanced tissue regeneration through increased chemotactic activity, fibroblast proliferation and collagenase synthesis [206]. Despite the scarcity of reports concerning the application of elastin-based dressings to DFU treatments, a recent study demonstrated that a protein gel comprised of elastin-like peptides loaded with keratinocyte growth factor (KGF) enhanced the re-epithelialization and granulation of wounds in diabetic mice [199], indicating that elastin can be considered an interesting naturally based polymeric material for enhancing DFU healing.

\subsubsection{DFU dressings based on synthetic polymers}

Due to the large number of available chemical monomeric entities of potential interest and due to the recent advances in polymer synthesis and processing methods, many new synthetic biocompatible, biodegradable/non-biodegradable polymers and copolymers have been developed in recent years [195]. Some of these polymeric materials can overcome the problems typically associated with natural polymers as they can be synthesized and processed in a highly controlled way, thus leading to homogeneous materials that will present constant and reproducible chemical and physical properties [173]. The risks of biological contamination are non-existent. In addition, some of these synthetic polymers are mainly degraded via chemical hydrolysis and are quite insensitive to a number enzymatic processes, and hence their degradation behavior will not vary greatly from patient to patient [173]. Synthetic polymers that are being used for the development of wound dressings, in particular those that can be used for DFU treatment, will be presented and discussed in the following section.

3.2.2.1. Poly(vinyl alcohol) (PVA). PVA is a hydrophilic, non-toxic, non-carcinogenic, biocompatible polymer obtained from vinyl acetate by alcoholysis, hydrolysis or aminolysis $[61,80,153]$. PVA has been widely used for tissue engineering and drug delivery applications, and besides its high hydrophilicity and water absorption capacity, it also presents an excellent capacity to be processed in the form of particles, fibers, textiles, sponges and films. Furthermore, it presents good chemical/enzymatic resistance, as well as good mucoadhesive and oxygen permeability properties [207209]. However, PVA exhibits some unfavorable mechanical properties (e.g. strength and flexibility), as well as a relatively poor thermal stability [210], though this can be improved by blending PVA with other polymers (including naturally based polymers such as chitosan, gelatin, dextran and hyaluronic acid) [211-213] or by adequate chemical or physical cross-linking $[61,208]$. Chemical cross-linking can be obtained by using glutaraldehyde, genipin, succinyl chloride, adipoyl chloride and sebacoyl chloride, while physical cross-linking can be obtained by repeated freeze-thawing cycles $[61,209,214]$. PVA is not chemically or enzymatically degradable in vivo but it may erode quite easily (by dissolution) and thus may not be useful as a long-term or permanent dressing [153].

PVA and its derivatives have already been used as wound dressings for conventional wounds, and have also been tested for diabetic wound treatments [215]. Enhanced healing results were obtained by incorporating NO into the PVA dressing since exogenous NO released increased collagen production, enhanced the quality of the granulation tissue and increased the wound strength. PVA has also been cross-linked with sodium carboxymethylcellulose and dextran to improve PVA water (and consequently exudate) swelling capacity as well as its water vapor transmission rate. Besides NO, PVA-based dressings have also been loaded with bioactive compounds such as gentamicin and ciprofloxacin since the efficient release of anti-bacterial drugs may help to improve complications in long-term healing [215,216].

3.2.2.2. Poly (ethylene glycol) (PEG)/Poly(ethylene oxide) (PEO). PEG is a polyether which is also known as poly(ethylene oxide) (PEO) or as poly(oxyethylene) (POE), depending on its molecular weight [80]. It is a hydrophilic, biocompatible, flexible, non-toxic and non-immunogenic material that is resistant to protein adsorption and can be synthesized by anionic or cationic polymerization of ethylene oxide [80,153,217].

PEG presents almost all of the favorable and unfavorable properties of PVA when wound dressing applications are envisaged [218]. Furthermore, its terminal hydroxyl groups can be derivatized to create PEG macromers that can participate in other chain or step polymerizations. PEG macromers have low toxicity, and can be coupled with peptides or growth factors and placed in situ to fill irregular sites $[80,217]$. Three major cross-linking methods have been used to prepare PEG-based hydrogels: radiation of linear or branched PEG polymers [219]; free radical polymerization of PEG acrylates [220]; and other specific chemical reactions, such as condensation reactions [220], Michael-type additions [221] and enzymatic reactions [222]. PEG acrylates such as PEG diacrylate, PEG dimethacrylate and multiarm PEG (n-PEG) 
acyrlate are the major types of macromers used for photopolymerization [217].

PEG can also be blended with other polymers such as chitosan, poly(lactic-co-glycolic acid) (PLGA) and poly(propylene fumarate) (PPF) in order to improve its inherent solubility, erosion, mechanical and thermal properties as well as its crystallinity and viscosity [218,223]. The formation of PEG-based block copolymers is also a viable option. PEG-based hydrogels have been used for many biomedical applications including wound dressings [218,224]. In addition, this type of hydrogel has already been demonstrated to be advantageous for diabetic wounds as it promotes proliferation of skin cells, enhanced collagen deposition and reduced scar formation [225-228]. As in the case of the previously discussed materials, PEG has also been associated with other polymers such as PCL, and can be loaded with growth factors such as EGF, bFGF, pbFGF or rhaFGF which help to increase the wound recovery rate, leading to improved vascularization, enhanced collagen deposition, and maturation and complete re-epithelialization [226,227,229,230].

3.2.2.3. Poly(vinyl pyrrolidone) (PVP). Like PVA and PEG, this hydrophilic and biocompatible material has been extensively used for a wide variety of pharmaceutical and biomedical applications (including wound dressings). This is mostly due to its water absorption and oxygen permeability properties [231,232]. PVP hydrogels can be produced at relatively low cost. This process is simple, safe and efficient $[218,233]$. Like the two above-described hydrophilic synthetic polymers (i.e. PVA and PEG), PVP is usually blended with other polymers (e.g. agar, cellulose or PEG) or cross-linked with carbodiimides in order to modify its solubility, delivery and erosion profiles, mechanical properties, softness and elasticity [218]. A significant improvement in wound healing of diabetic rats was achieved after application of a new NO delivery platform based on grafting $S$-nitrosothiols, derived from endogenous glutathione (GSH) or its oligomeric derivatives, phytochelatins, onto poly(vinyl methyl ether co-maleic anhydride) and the subsequent formation of interpolymer complexes with PVP. This complex provides controlled release of NO for more than 10 days, and a single topical application of the NO-controlled delivery system accelerates wound closure as compared with the control [234]. These results suggested that NO-releasing interpolymer complexes could be potentially useful for diabetic wound healing.

3.2.2.4. Polyurethanes (PUs). Polyurethanes are synthesized by condensation and polymerization methods from a wide range of bifunctional or higher-order functional monomers. This will lead to versatile polymeric materials that may present quite different chemical, physical and biological properties [235], such as hydrophilic/hydrophobic characteristics, water sorption, permeation and degradation profiles, as well as thermal and mechanical properties [236]. As an example, PUs can lead to hard, flexible or elastomeric materials, even without covalent cross-linking [237]. PUs are also non-toxic, sterilizable, non-adherent and non-allergenic [238]. Furthermore, PUs may be easily cross-linked, blended with other synthetic and/or natural-based polymers, and processed in the form of particles, fibers, films, foams and hydrogels [239]. PU-based nanofibers showed controlled evaporative water loss and promoted wound fluid drainage, which are essential characteristics for wound dressing materials $[240,241]$. When compared to other conventional dressings, some PU-based foam dressings showed higher healing capacities [237,238,241,242]. A dressing constituted of polymeric fibers with repeated units containing urethane groups (aliphatic polyurethane, aromatic polyurethane, aliphatic polyurethane, aromatic polyurethane or a combination of them) was recently patented and presented as effective for the treatment of chronic wounds such as DFUs [237]. The improved capacity to manage wound exudates justifies the regular use of
PU-derived materials (mainly in the form of films or foams) in multilayer dressings in order to optimize their healing capacity. As an example, the commercial wound dressing Meliplex ${ }^{\circledR} \mathrm{Ag}$ (Molnlycke Health Care, Sweden) comprises a silicone wound contact layer, an absorbent material (polyurethane foam pad), an anti-bacterial (a silver compound, silver sulfate) and a vapor-permeable waterproof film to absorb exudate and to maintain a moist wound environment. It can be used on exuding wounds at risk of infection such as leg ulcers, DFUs, pressure ulcers and burns [243]. As discussed before, PU-based dressings have also been loaded with bioactive compounds to shorten healing periods. A wound dressing containing an antimicrobial therapeutic agent (e.g. penicillin, erythromycin, chlorohexidine, triclosan), a pain-relieving substance (e.g. ibuprofen) and protease inhibitors (e.g. MMP-9, elastase, MMP-8, MMP-12) in a barrier layer made of collagen/ polylactide/polyglycolide or polyurethane was recently patented [238]. This layer breaks down in contact with wounds, releasing the therapeutic substances into the wound. This invention was developed for chronic wound treatment, such as venous ulcers or DFUs. These and other examples are summarized in Table 2.

3.2.2.5. Poly (hydroxyethyl methacrylate) (PHEMA). PHEMA-based polymers and copolymers are important biocompatible, non-biodegradable materials that can lead to the formation of hydrogels to be employed in various different biomedical and pharmaceutical applications [244]. Their final chemical, physical, sorption and permeability properties will depend on the synthesis method and conditions, on the chemical nature and proportions of the employed co-monomers and cross-linkers, as well as on the final degree of cross-linking [218]. PHEMA-based polymers usually present good oxygen permeability, good water sorption and transmission rates, high biocompatibility and non-toxicity [244,245]. PHEMA-based hydrogels have been used for artificial skin manufacturing and wound dressing applications [153,218] and many bioactive substances have been incorporated into these materials [153]. An interesting example is the case of a hybrid dressing consisting of a pHEMA core (containing a light-activated NO donor) and a PU coating for use on chronic wounds [246]. One major advantage of this material is the fact that NO release can be controlled by light exposure. The dressing can be illuminated from time to time to deliver NO only to the wound site, maintaining antiseptic conditions. This approach might be superior to simple washing of the affected area with conventional solutions such as hydrogen peroxide.

PHEMA and PEG have been combined to develop a hydrogel dressing that can bind covalently to MMP inhibitors and promote the healing of chronic wounds as DFUs. This patented dressing ensures that MMPs in the chronic wound fluid are inhibited (thus reducing their proteolytic content) while guaranteeing that the necessary MMP levels for normal healing are not affected in the wound bed [247].

3.2.2.6. Poly ( $\alpha$-esters) (PLA, PGA, PLGA, PCL). Polylactide (PLA) is one of the most popular aliphatic polyesters since it presents relatively high strength and an appropriate degradation rate for most drug delivery and tissue engineering systems [248]. In fact, PLA possesses good mechanical characteristics, controlled degradability and excellent biocompatibility. However, its strong hydrophobicity limits some of its potential applications [248-250].

Polyglycolic acid (PGA) is another poly( $\alpha$-ester) that presents a relatively hydrophilic nature and degrades faster than PLA in aqueous solutions or in vivo. To obtain intermediate degradation rates between PGA and PLA, several copolymers of lactic acid and of glycolic acid poly(lactic-co-glycolic acid) (PLGA) can be synthesized $[250,251]$.

PLGA is also a biodegradable polymer with strong biocompatibility, controlled biodegradability and potential for sustained re- 
lease of various bioactive substances [252]. Furthermore, it can be processed into many different forms-powder, pellets, fibers, nanoparticles, etc. PLGA microspheres loaded with rhEGF were demonstrated to enhance the growth rate of fibroblasts, and it was also observed that wounds in diabetic rats healed more efficiently than when pure rhEGF is used $[252,253]$.

Dong et al. [252] prepared PLGA microspheres loaded with rhEGF by a solvent-evaporation technique. These microspheres were small in size and presented a high drug encapsulation capacity ( $86 \%$ ). Furthermore, rhEGF-loaded microspheres loaded into the wound site enhanced the growth rate of fibroblasts, and it was also observed that wounds in diabetic rats healed more efficiently than when pure rhEGF is used. Chu et al. [253] used a modified doubleemulsion method to prepare rhEGF-loaded PLGA nanoparticles to heal diabetic ulcers. In diabetic rats, these rhEGF-loaded nanoparticles promoted a faster healing rate as well as fibroblast proliferation.

These copolymers can be applied in skin tissue regeneration and suture applications, and have been approved by the FDA for several biomedical and pharmaceutical applications [250]. The incorporation of drugs and other bioactive substances into poly( $\alpha$-hydroxy acids) has been done with DFU applications in mind. Xu et al. [254] reported the incorporation of a hydrophilic antibiotic drug, tetracycline hydrochloride (TCH), into an electrospun PEG-PLA nanofibrous membrane. This drug-impregnated membrane demonstrated sustained release of TCH over 6 days and was effective at inhibiting growth of Staphylococcus aureus. As observed before for other polymer-based dressings, the loading of growth factors into PLA-based materials to stimulate the wound healing process is also an option for DFU treatment. As an example, bFGF was embedded into ultrafine PLA fibers with a core-sheet structure [99]. An initially low burst release was achieved, followed by controlled release for around 4 weeks, a profile that is interesting for application in chronic wounds. Results also showed a higher wound recovery rate with complete re-epithelialization, regeneration of skin appendages, higher density and mature capillary vessels in bFGF-loaded scaffolds when compared with fibers without bFGF and after 2 weeks of treatment. Moreover, it also presented enhanced collagen deposition, an ECM remodeling process and components of collagen fibers similar to normal tissues.

Polycaprolactone (PCL) is another biodegradable and biocompatible poly( $\alpha$-ester) which has been studied for tissue regeneration and wound healing applications since it promotes a faster healing and reduced inflammatory infiltrate [255]. However, PCL degrades at a significantly slower rate than PLA, PGA and PLGA [256]. This slow degradation makes PCL less attractive for this type of biomedical application, but more attractive for sutures, longterm implants and controlled-release applications [250].

Merrel et al. [255] developed PCL nanofibers as a delivery vehicle for curcumin for diabetic wound healing applications [255]. Curcumin is a natural phenolic compound with anti-oxidant and anti-inflammatory properties. The prepared curcumin-loaded nanofibers reduced inflammatory induction from mouse monocyte-macrophages. In addition they increased the rate of wound closure in a STZ-induced diabetic mouse model. These results demonstrated that these curcumin-loaded PCL nanofibers are bioactive and have potential to be applied as wound dressings with anti-oxidant and anti-inflammatory properties for DFU treatment.

\section{Future trends and perspectives}

DFUs are a frequent complication of diabetes that may lead to severe and persistent infection and, in extreme cases, to lowerextremity amputation. Therapeutics usually involves the use of dressings, aiming to enhance the life quality of DFU patients, to alleviate pain, to deliver drugs and to reduce odors. The necessity to develop and improve the efficacy of wound dressings, particularly suitable for DFU treatment, has been a challenge for both researchers and clinicians. An ideal dressing should confer moisture balance, protease sequestration, growth factor stimulation, antimicrobial activity, oxygen permeability and capacity to promote autolytic debridement that facilitates the production of granulation tissue and the re-epithelialization process. In addition, it should have a prolonged time of action, high efficiency and improved sustained drug release in the case of medicated systems.

New and recent alternatives to conventional dressings have been developed; these include mixing different polymers and using more efficient cross-linking methods to create improved materials that guarantee an optimal wound environment. As discussed, natural (chitosan, hyaluronic acid, cellulose, alginate, collagen, fibrin) or synthetic (PVA, PEG, PVP, PU, PHEMA, $\operatorname{poly}(\alpha-$ esters)) polymers have been combined or cross-linked (e.g. with genipin, oxidized dextran or glutaraldehyde) for this purpose. Furthermore, medicated dressings have been examined as a means to efficiently deliver drugs or other bioactive substances that had previously been demonstrated to improve DFU treatment. Dressings loaded with antimicrobials/antibiotics (to decrease infection), platelet-derived substances, patients' own stem cells, growth factors and peptides act to balance (through up-regulation of growth factors and cytokines and down-regulation of destructive proteolysis) the biochemical events of inflammation in the chronic wound and to improve healing. Some studies dealing with the incorporation of natural extracts showed great potential in the treatment of DFUs; however, these findings do not yet represent a practical option since application of these compounds tends be very expensive and difficult to regulate/control. Therefore, and in the near future, research will certainly focus on the development of more efficient and less expensive biocompatible and biodegradable medicated dressings that can deliver important DFU healing factors to the wound site in order to improve patient care and quality of life.

\section{Acknowledgements}

This work was financially supported by COMPETE and Fundação para a Ciência e Tecnologia (FCT-MES) under contracts, PTDC/SAUBEB/71395/2006, PTDC/SAU-MII/098567/2008, PTDC/SAU-FAR/ 121109/2010, PEst-C/SAU/LA0001/2011, by EFSD/JDRF/Novo Nordisk European Programme in Type 1 Diabetes Research and Sociedade Portuguesa de Diabetologia. L.I.F.M. and A.M.A.D. acknowledge FCT-MES for their fellowships SFRH/BD/60837/2009 and SFRH/ BPD/40409/2007, respectively.

\section{Appendix A. Figures with essential colour discrimination}

Certain figures in this article, particularly Figures 2 and 3, are difficult to interpret in black and white. The full colour images can be found in the on-line version, at http://dx.doi.org/10.1016/ j.actbio.2013.03.033.

\section{References}

[1] Shaw JE, Sicree RA, Zimmet PZ. Global estimates of the prevalence of diabetes for 2010 and 2030. Diabetes Res Clin Pract 2010;87:4-14.

[2] Whiting DR, Guariguata L, Weil C, Shaw J. IDF Diabetes Atlas: global estimates of the prevalence of diabetes for 2011 and 2030. Diabetes Res Clin Pract 2011;84:311-21.

[3] Chittleborough CR, Grant JF, Phillips PJ, Taylor AW. The increasing prevalence of diabetes in South Australia: the relationship with population ageing and obesity. Public Health 2007;121:92-9.

[4] Ahmed I, Glodstein B. Diabetes mellitus. Clin Dermatol 2006;24:237-46.

[5] Daneman D. Type 1 diabetes. Lancet 2006;367:847-58.

[6] Vehik K, Dabelea D. The changing epidemiology of type 1 diabetes: why is it going through the roof? Diabetes Metab Res Rev 2011;27:3-13. 
[7] Wang J, Luben R, Khaw KT, Bingham S, Wareham NJ, Forouhi NG. Dietary energy density predicts the risk of incident type 2 diabetes: the European Prospective Investigation of Cancer (EPIC)-Norfolk Study. Diabetes Care 2008;31:2120-5.

[8] Knowler WC, Barrett-Connor E, Fowler SE, Hamman RF, Lachin JM, Walker EA, et al. Reduction in the incidence of type 2 diabetes with lifestyle intervention or metformin. N Engl J Med 2002;346:393-403.

[9] Kahn SE. The relative contributions of insulin resistance and beta-cell dysfunction in the pathophysiology of type 2 diabetes. Diabetologia 2008;46:3-19.

[10] McCance DR. Pregnancy and diabetes. Best Pract Res Clin Endocrinol Metab 2011;25:945-58.

[11] Kim C, Newton KM, Knopp RH. Gestational diabetes and the incidence of type 2 diabetes: a systematic review. Diabetes Care 2002;25:1862-8.

[12] Ali S, Dornhorst A. Diabetes in pregnancy: health risks and management. Postgrad Med J 2011;57:417-27.

[13] Vague J, Vague P, Tramoni M, Vialette B. Obesity and diabetes. Acta Diabetol 1980;17:87-9.

[14] Mokdad A, Ford E, Bowman B. Prevalence of obesity, diabetes and obesityrelated health risk factors. J Am Med Assoc 2003;289:76-9.

[15] Haslam D. Obesity and diabetes: the links and common approaches. Prim Care Diab 2010;4:105-12.

[16] Schamseddeen H, Getty JZ, Hamdallah IN, Ali MR. Epidemiology and economic impact of obesity and Type 2 diabetes. Surg Clin North Am 2011;91:1163-72.

17] Fontbonne A, Eschwege E, Cambien F, Richard JL, Ducimetiere P, Thibult N et al. Hypertriglyceridaemia as a risk factor of coronary heart disease mortality in subjects with impaired glucose tolerance or diabetes. Results from the 11-year follow-up of the Paris Prospective Study. Diabetologia 1989;32:300-4.

[18] Srikanth S, Deedwania P. Primary and secondary prevention strategy for cardiovascular disease in diabetes mellitus. Cardiovasc Clin 2011;29:47-70.

[19] Gimenez M, Lopez JJ, Castell C Conget I. Hypoglycaemia and cardiovascular disease in Type 1 Diabetes. Results from the Catalan National Public Health registry on insulin pump therapy. Diabetes Res Clin Pract 2012;96:e23-5.

[20] Andersen AR, Christiansen JS, Andersen JK, Kreiner S, Deckert T. Diabetic nephropathy in type 1 (insulin-dependent) diabetes: an epidemiological study. Diabetologia 1983;25:496-501.

[21] Mogensen CE, Christensen CK. Predicting diabetic nephropathy in insulindependent patients. N Engl J Med 1984;311:89-93.

[22] Mohammedi K, Maimaitiming S, Emery N, Bellili-Munõz N, Roussel R, Fumeron F, et al. Allelic variations in superoxide dismutase-1 (SOD1) gene are associated with increased risk of diabetic nephropathy in type 1 diabetic subjects. Mol Genet Metab 2011:104:654-60.

[23] Zhang S, Zhang Y, Wei X, Zhen J, Wang Z, Li M, et al. Expression and regulation of a novel identified TNFAIP8 family is associated with diabetic nephropathy. BBA Mol Basis Dis 2010;1802:1078-86.

[24] Leibowitz HM, Krueger DE, Maunder LR, Milton RC, Kini MM, Kahn HA, et al. The Framingham Eye Study monograph: An ophthalmological and epidemiological study of cataract, glaucoma, diabetic retinopathy, macular degeneration, and visual acuity in a general population of 2631 adults, 19731975. Surv Ophthalmol 1980;24:335-610.

[25] Klein R, Klein BE, Moss SE, Davis MD, DeMets DL. The Wisconsin epidemiologic study of diabetic retinopathy. III. Prevalence and risk of diabetic retinopathy when age at diagnosis is 30 or more years. Arch Ophthalmol 1984;102:527-32.

[26] Kim BY, Kim CH, Jung CH, Mok JO, Suh KI, Kang SK. Association between subclinical hypothyroidism and severe diabetic retinopathy in Korean patients with type 2 diabetes. Endocr J 2011;58:1065-70.

[27] Chen H, Zheng Z, Huang Y, Guo K, Lu J, Zhang L, et al. A microalbuminuria threshold to predict the risk for the development of diabetic retinopathy in type 2 diabetes mellitus patients. PLoS ONE 2012;7:e36718.

[28] Brown MJ, Martin JR, Asbury AK. Painful diabetic neuropathy. A morphometric study. Arch Neurol 1976;33:164-71.

[29] Dyck PJ, Kratz KM, Karnes JL, Litchy WJ, Klein R, Pach JM, et al. The prevalence by staged severity of various types of diabetic neuropathy, retinopathy, and nephropathy in a population-based cohort: the Rochester Diabetic Neuropathy Study. Neurology 1993;43:817-24.

[30] Silva L, Carvalho E, Cruz MT. Role of neuropeptides in skin inflammation and its involvement in diabetic wound healing. Expert Opin Biol Ther 2010;10:1427-39.

[31] Kim SK, Lee KJ, Hahm JR, Lee SM, Jung TS, Jung JH, et al. Clinical significance of the presence of autonomic and vestibular dysfunction in diabetic patients with peripheral neuropathy. Diab Metab J 2012;36:64-9.

[32] Enoch S, Leaper DJ. Basic science of wound healing. Surgery 2008;26:31-7.

[33] Li J, Chen J, Kirsner R. Pathophysiology of acute wound healing. Clin Dermatol 2007;25:9-18

[34] Sidhu GS, Mani H, Gaddipati JP, Singh AK, Seth P, Banaudha KK, et al Curcumin enhances wound healing in streptozotocin induced diabetic rats and genetically diabetic mice. Wound repair and regeneration: official publication of the Wound Healing Society [and] the European Tissue Repair Society 1999;7:362-74.

[35] Falanga V. Wound healing and its impairment in the diabetic foot. Lancet 2005;366:1736-43.

[36] Delavary BM, Veer WM, Egmond M, Niessen FB, Beelen RHJ. Macrophages in skin injury and repair. Immunobiology 2011;216:753-62.
[37] Monaco JL, Lawrence WT. Acute wound healing: and overview. Clin Plast Surg 2003;30:1-12.

[38] Singer AJ, Clark RA. Cutaneous wound healing. N Engl J Med 1999;341:738-46.

[39] Rodero MP, Khosrotehrani K. Skin wound healing modulation by macrophages. Int J Clin Exp Pathol 2010;3:643-53.

[40] Wilgus TA. Immune cells in the healing skin wound: influential players at each stage of repair. Pharmacol Res 2008;58:112-6.

[41] Tsirogianni AK, Moutsopoulos NM, Moutsopoulos HM. Wound healing: immunological aspects. Injury 2006;37:S5-S22.

[42] Schreml S, Szeimies R, Prantl L, Landthaler M, Babilas P. Wound healing in 21st century. J Am Acad Dermatol 2010;63:866-81.

[43] Tellechea A, Leal E, Veves A, Carvalho E. Inflammatory and angiogenic abnormalities in diabetic wound healing: role of neuropeptides and therapeutic perspectives. Open Circ Vasc J 2009;3:43-55.

[44] Basic-Kes V, Zavoreo I, Rotim K, Bornstein N, Rundek T, Demarin V. Recommendations for diabetic polyneuropathy treatment. Acta Clin Croat 2011;50:289-302.

[45] Aring AM, Jones DE, Falko JM. Evaluation and prevention of diabetic neuropathy. Am Fam Physician 2005;71:2123-8.

[46] Vinik A, Ullal J, Parson HK, Casellini CM. Diabetic neuropathies: clinica manifestions and current treatment options. Nat Rev Endocrinol 2006;2: 269-81.

[47] Boulton AJ, Malik RA, Arezzo JC, Sosenko JM. Diabetic somatic neuropathies. Diabetes Care 2004;27:1458-86.

[48] Rathur HM, Bloulton AJM. Recent advances in the diagnosis and management of diabetic neuropathy. J Bone Joint Surg 2005;87:1605-10.

[49] Snyder BJ, Waldman BJ. Venous thromboembolism prophylaxis and wound healing in patients undergoing major orthopedic surgery. Adv Skin Wound Care 2009;22:311-5.

[50] Lobmann R, Zemlin C, Motzkau M, Reschke K, Lehnert H. Expression of matrix metalloproteinases and growth factors in diabetic foot wounds treated with a protease absorbent dressing. J Diabetes Complications 2006;20:329-35.

[51] Liu Y, Min D, Bolton T, Nube V, Twigg SM, Yue DK, et al. Increased Matrix Mettaloproteinase-9 predicts poor wound healing in diabetic foot ulcers. Diabetes Care 2009;32:e137.

[52] Guo S, Dipietro LA. Factors affecting wound healing. J Dent Res 2010;89: 219-29.

[53] Acosta JB, del Barco DG, Vera DC, Savigne W, Lopez-Saura P, Guillen Nieto G, et al. The pro-inflammatory environment in recalcitrant diabetic foot wounds. Int Wound J 2008;5:530-9.

[54] Blakytny R, Jude EB. Altered molecular mechanisms of diabetic foot ulcers. Int J Low Extrem Wounds 2009;8:95-104.

[55] Bloomgarden ZT. The diabetic foot. Diabetes Care 2008;31:372-6.

[56] Brem H, Tomic-Canic M. Cellular and molecular basis of wound healing in diabetes. J Clin Invest 2007:117:1219-22.

[57] Muller M, Trocme C, Lardy B, Morel F, Halimi S, Benhamou PY. Matrix metalloproteinases and diabetic foot ulcers: the ratio of MMP-1 to TIMP-1 is a predictor of wound healing. Diab Med 2008;25:419-26.

[58] Pradhan 1, Nabzdyk C, Andersen N, LoGerfo F, Veves A. Inflammation and neuropeptides: the connection in diabetic wound healing. Expert Reviews in Molecular Medicine 2009;11:1-24.

[59] O'Loughlin A, O'Brien T. Topical stem and progenitor cell therapy for diabetic foot ulcers. Stem Cells Clin Res 2011;978:579-604

[60] Mulder G, Armstrong D, Seaman S. Diabetic foot ulcerations: dressings. Wounds 2003;15:4-15

[61] Jannesari M, Varshosaz J, Morshed M, Zamani M. Composite poly(vinyl alcohol)/poly(vinyl acetate) electrospun nanofibrous mats as a novel wound dressing matrix for controlled release of drugs. Int $\mathrm{J}$ Nanomed 2011;6:993-1003.

[62] Cavanagh PR, Lipsky BA, Bradbury AW, Botek G. Treatment for diabetic foot ulcers. Lancet 2005;366:1725-35.

[63] Leung PC. Diabetic foot ulcers-a comprehensive review. Surgeon 2007;5: 219-31.

[64] Oyibo SO, Jude EB, Tarawneh I, Nguyen HC, Harkless LB, Boulton AJM. A comparison of two diabetic foot ulcer classification systems: the Wagner and the University of Texas wound classification systems. Diabetes Care 2001;24:84-8.

[65] ÓDonnell TF, Lau J. A systematic review of randomized controlled trials of wound dressings for chronic venous ulcer. Journal of Vascular Surgery 2006;44:1118-25.

[66] Morin RJ, Tomaselli NL. Interactive dressings and topical agents. Clin Plast Surg 2007;34:643-58.

[67] Lloyd LL, Kennedy JK, Methacanon P, Paterson M, Knill CJ. Carbohydrate polymers as wound management aids. Carbohydr Polym 1998;37: 315-22.

[68] Mulder M. The selection of wound care products for wound bed preparation Prof Nurs Today 2011:30:15-21.

[69] Harding KG, Jones V, Price P. Topical treatment: which dressing to choose Diabetes Metab Res Rev 2000;16(Suppl. 1):S47-50.

[70] Morton LM, Phillips TJ. Wound healing update. Semin Cutan Med Surg 2012;31:33-7.

[71] Wittaya-areekul S, Prahsarn C. Development and in vitro evaluation of chitosan-polysaccharides composite wound dressings. Int J Pharm 2006;313:123-8. 
[72] Boateng JS, Matthews KH, Stevens HN, Eccleston GM. Wound healing dressings and drug delivery systems: a review. J Pharm Sci 2008;97: 2892-923.

[73] Fonder MA, Lazarus GS, Cowan DA, Aronson-Cook B, Kohli AR, Mamelak AJ. Treating the chronic wound: a practical approach to the care of nonhealing wounds and wound care dressings. J Am Acad Dermatol 2008;58:185-206.

[74] Hilton JR, Williams DT, Beuker B, Miller DR, Harding KG. Wound dressings in diabetic foot disease. Clin Infect Dis 2004;39(Suppl. 2):S100-3.

[75] Fletcher J, Moore Z, Anderson I, Matsuzaki K. Pressure ulcers and hydrocolloids. Wound Int 2011;2:1-6.

[76] Dumville JC, Deshpande S, O’Meara S, Speak K. Hydrocolloid dressings for healing diabetic foot ulcers. Cochrane Database Syst Rev 2012;2:CD009099.

[77] Jeffcoate WJ, Price P, Harding KG. Wound healing and treatments for people with diabetic foot ulcers. Diabetes Metab Res Rev 2004;20(Suppl. 1):S78-89.

[78] McIntosh C. Are hydrocolloid dressings suitable for diabetic foot ulcers? Wound Essent 2007;2:170-2.

[79] Dumville JC, Soares MO, O'Meara S, Cullum N. Systematic review and mixed treatment comparison: dressings to heal diabetic foot ulcers. Diabetologia 2012;55:1902-10.

[80] Slaughter BV, Shahana SK, Fisher OZ, Khademhosseini A, Peppas NA. Hydrogels in regenerative medicine. Adv Mater 2009;21:3307-29.

[81] Edwards J, Stapley S. Debridment of diabetic foot ulcers. Cochrane Database Syst Rev 2010;20:1-44.

[82] Skorkowska-Telichowska K, Czemplik M, Kulma A, Szopa J. The local treatment and available dressings for chronic wounds. J Am Acad Dermato 2011;5:1-11.

[83] Weller C, Sussman G. Wound dressings update. J Pharm Pract Res 2006;36:318-24

[84] Jayakumar R, Prabaharan M, Sudheesh Kumar PT, Nair SV, Tamura H. Biomaterials based on chitin and chitosan in wound dressing applications. Biotechnol Adv 2011;29:322-37.

[85] Lee Y, Chang J, Yang M, Chien C, Lai W. Aceleration of wound dressing in diabetic rats by layered hydrogel dressing. Carbohydr Polym 2012;88:809-19.

[86] Meinel A, Germershaus O, Luhmann T, Merkle HP, Meinel L. Electrospun matrices for localized drug delievery: current technologies and selected biomedical applications. Eur J Pharm Biopharm 2012;81:1-13.

[87] Nussinovitch A, Ben-Zion OM. Depolymerized polysaccharide-based hydroge adhesive and methods of use therefore. US Patent 20110190401 A1; 2011.

[88] Nisbet L. Wound dressing materials. US Patent 20120135062 A1; 2012.

[89] Matsumoto Y, Kuroyanagi Y. Development of a wound dressing composed of hyaluronic acid sponge containing arginine and epidermal growth factor. J Biomater Sci Polym Ed 2010;21:715-26.

[90] Hong HJ, Jin SE, Park JS, Ahn WS, Kim CK. Accelerated wound healing by smad3 antisense oligonucleotides-impregnated chitosan/alginate polyelectrolyte complex. Biomaterials 2008;29:4831-7.

[91] Altman AM, Yan Y, Matthias N, Bai X, Rios C, Mathur AB, et al. IAFTS collection: human adipose-derived stem cells seeded on a silk fibroinchitosan scaffold enhance wound repair in a murine soft tissue injury model. Stem Cells 2009;27:250-8.

[92] Suganya S, Ram TS, Lakshmi BS, Giridev VR. Herbal drug incorporated antibacterial nanofibrous mat fabricated by electrospinning: an excellent matrix for wound dressings. J Appl Polym Sci 2011:121:2893-9.

[93] Zoher K, Kolli ME, Riahi F, Doufnoune R. Preparation and characterization of hydrocolloid biopolymer-based films for dressings application. Int J Polym Mater 2009;58:665-80.

[94] Zahedi P, Rezaeian I, Ranaei-Siadat S, Jafari S, Supaphol P. A review on wound dressings with an emphasis on electrospun nanofibrous polymeric bandages. Polym Adv Technol 2010;21:77-95.

[95] Sionkowska A. Current research on the blends of natural and synthetic polymers as new biomaterials: review. Prog Polym Sci 2011;36:1254-76.

[96] Muzzarelli RAA, Muzzarelli C. Chitosan chemistry: relevance to the biomedical sciences. Adv Polym Sci 2005;186:151-209.

[97] Seetharaman S, Shanmugasundaram N, Stowers RS, Mullens C, Baer DG, Suggs LJ, et al. A PEGylated fibrin-based wound dressing with antimicrobial and angiogenic activity. Acta Biomater 2011;7:2787-96.

[98] Breen AM, Dockery P, O’Brien T, Pandit AS. The use of therapeutic gene eNOS delivered via a fibrin scaffold enhances wound healing in a compromised wound model. Biomaterials 2008;29:3143-51.

[99] Yang Y, Xia T, Zhi W, Wei L, Weng J, Zhang C, et al. Promotion of skin regeneration in diabetic rats by electrospun core-sheath fibers loaded with basic fibroblast growth factor. Biomaterials 2011;32:4243-54.

[100] Tabata Y. Biomaterial technology for tissue engineering applications. Journal of the Royal Society Interface 2009:S311-24.

[101] Malafaya PB, Silva GA, Reis RL. Natural-origin polymers as carriers and scaffolds for biomolecules and cell delivery in tissue engineering applications. Adv Drug Deliv Rev 2007;59:207-33.

[102] Sell SA, Wolfe PS, Garg K, McCool JM, Rodriguez IA, Bowlin GL. The use of natural polymers in tissue engineering: a focus on electrospun extracellular matrix analogues. Polym Adv Technol 2010;2:522-53.

[103] Huang S, Fu X. Naturally derived materials-based cell and drug delivery systems in skin regeneration. J Control Release 2010;142:149-59.

[104] Tessmar JK, Gopferich AM. Matrices and scaffolds for protein delivery in tissue engineering. Adv Drug Deliv Rev 2007;58:274-91.
[105] Dai T, Tanaka M, Huang YY, Hamblin MR. Chitosan preparations for wounds and burns: antimicrobial and wound-healing effects. Expert Rev Anti Infect Ther 2011;9:857-79.

[106] Khoushab F, Yamabhai M. Chitin research revisited. Mar Drugs 2010;8:1988-2012.

[107] Madihally SV. Processing chitosan for tissue regeneration. Curr Trends Polym Sci $2011 ; 15: 83-8$

[108] Koide SS. Chitin-chitosan: properties, benefits and risks. Nutr Res 1998;13:1091-101.

[109] Kim IY, Seo SJ, Moon HS, Yoo MK, Park IY, Kim BC, et al. Chitosan and its derivatives for tissue engineering applications. Biotechnol Adv 2008;26:1-21.

[110] Jayakumar R, Prabaharan M, Nair SV, Tamura H. Novel chitin and chitosan nanofibers in biomedical applications. Biotechnol Adv 2010;28:142-50.

[111] Dash M, Chiellini F, Ottenbrite RM, Chiellini E. Chitosan-a versatile semisynthetic polymer in biomedical. Progress in Polymer Science 2011;678.

[112] Rinaudo M. Chitin and chitosan: properties and applications. Prog Polym Sci 2006;31:603-32.

[113] Chatelet C, Damour O, Domard A. Influence of the degree of acetylation on some biological properties of chitosan films. Biomaterials 2001;22:261-8.

[114] Pérez RA, Won J, Knowles JC, Kim H. Naturally and synthetic smart composite biomaterials for tissue regeneration. Advanced Drug Delivery Reviews 2012.

[115] Tan Y, Han F, Ma S, Yu W. Carboxymethyl chitosan prevents formation of broad-spectrum biofilm. Carbohydr Polym 2011;84:1365-70.

[116] Santos KSCR, Silva HSRC, Ferreira EI, Bruns RE. 32 Factorial design and response surfasse analysis optimization of $\mathrm{N}$-carboxybutylchitosan synthesis. Carbohydr Polym 2005;59:37-42.

[117] Dias AM, Seabra IJ, Braga MM, Gil MH, de Sousa HC. Supercritical solvent impregnation of natural bioactive compounds in N-carboxybutyl chitosan membranes for the development of topical wound healing applications. J Control Release 2010;148:e33-5.

[118] Dai YN, Li P, Zhang JP, Wang AQ, Wei Q. A novel pH sensitive N-succinyl chitosan/alginate hydrogel bead for nifedipine delivery. Biopharm Drug Dispos 2008;29:173-84

[119] Han T, Nwe N, Furuike T, Tokura S, Tamura H. Methods of N-acetylated chitosan scaffolds and its in vitro biodegradation by lysozyme. J Biomed Sci Eng 2012;5:15-23.

[120] Chen R, Wang G, Chen C, Ho H, Shen M. Development of a new N-O(carboxymethyl)/chitosan/collagen matrixes as a wound dressing. Biomacromolecules 2006;7:1058-64.

[121] Mattioli-Belmonte M, Gigante A, Muzzarelli RAA, Politano R, Benedittis A, Specchia N, et al. N-N-dicarboxymethyl chitosan as delivery agent for bone morphogenetic protein in the repair of articular cartilage. Med Biol Eng Comput 1999;37:130-4.

[122] Weng L, Romanov A, Rooney J, Chen W. Non-cytotoxic, in siu gelable hydrogels composed of $\mathrm{N}$-carboxyethyl chitosan and oxidized dextran. Biomaterials 2008;29:3905-13.

[123] Zhang C, Ping Q, Zhang H, Shen J. Synthesis and characterization of watersoluble O-succinyl-chitosan. Eur Polym J 2003;39:1629-34.

[124] Yin L, Fei L, Cui F, Tang C, Yin C. Superporous hydrogels containing poly(acrylic acid-co-acrylamide)/o-carboxymethyl chitosan interpenetrating polymer networks. Biomaterials 2007;28:1258-66.

[125] Berscht PC, Nies B, Liebendorfer A, Kreuter J. Incorporation of basic fibroblast growth factor into methylpyrrolidinone chitosan fleeces and determination of the in vitro release characteristics. Biomaterials 1994;15:593-600.

[126] Censi R, Di Martino P, Vermonden T, Hennink WE. Hydrogels for protein delivery in tissue engineering. I Control Release 2012;161:680-92.

[127] Azad AK, Sermsintham N, Chandrkrachang S, Stevens WF. Chitosan membrane as a wound-healing dressing: characterization and clinical application. J Biomed Mater Res B Appl Biomater 2004;69:216-22.

[128] Kumar MNVR. A review of chitin and chitosan applications. React Funct Polym 2000;46:1-27.

[129] Saranya N, Moorthi A, Saravanan S, Devi MP, Selvamurugan N. Chitosan and its derivatives for gene delivery. Int J Biol Macromol 2011;48:234-8.

[130] Bhattarai N, Gunn J, Zhang M. Chitosan-based hydrogels for controlled, localized drug delivery. Adv Drug Deliv Rev 2010;62:83-99.

[131] Takei T, Nakahara H, Ijima H, Kawakami K. Synthesis of a chitosan derivative soluble at neutral $\mathrm{pH}$ and gellable by freeze-thawing, and its application in wound care. Acta Biomater 2012;8:686-93.

[132] Muzzarelli RAA. Chitins and chitosans for the repair of wounded skin, nerve, cartilage and bone. Carbohydr Polym 2009;76:167-82.

[133] Patterson J, Martino MM, Hubbell JA. Biomimetic materials in tissue engineering. Mater Today 2010;13:14-22.

[134] Liao YH, Jones SA, Forbes B, Martin GP, Brown MB. Hyaluronan pharmaceutical characterization and drug delivery. Drug Deliv 2005;12:327-42.

[135] Price RD, Berry MG, Navsaria HA. Hyaluronic acid: the scientific and clinical evidence. J Plast Reconstr Aesthet Surg 2007;60:1110-9.

[136] Galeano M, Polito F, Bitto A, Irrera N, Campo GM, Avenoso A, et al. Systemic administration of high-molecular weight hyaluronan stimulates wound healing in genetically diabetic mice. Biochim Biophys Acta 2011;1812:752-9.

[137] Xu H, Ma L, Shi H, Gao C, Han C. Chitosan-hyaluronic acid hybrid film as a novel wound dressing: in vitro and in vivo studies. Polym Adv Technol 2007; 18:869-75. 
[138] Uppal R, Ramanswamy GN, Arnold C, Goodband R, Wang Y. Hyaluronic acid nanofiber wound dressing-production, characterization, and in vivo behavior. J Biomed Mater Res 2011;97B:20-9.

[139] Vazquez JR, Short B, Findlow AH, Nixon BP, Boulton AJM, Armstrong DG. Outcomes of hyaluronan therapy in diabetic foot wounds. Diabetes Res Clin Pract 2003;59:123-7.

[140] Gall Y. Hyaluronic acid: structure, metabolism and implication in cicatrization. Ann Dermatol Venereol 2010;137(Suppl. 1):S30-9.

[141] Mano JF, Silva GA, Azevedo HS, Malafaya PB, Sousa RA, Silva SS, et al. Natural origin biodegradable systems in tissue engineering and regenerative medicine: present status and some moving trends. J R Soc Interface 2007;4:999-1030.

[142] Solway DR, Clark WA, Levinson DJ. A parallel open-label trial to evaluate microbial cellulose wound dressing in the treatment of diabetic foot ulcers. Int Wound J 2011;8:69-73.

[143] Sannino A, Demitri C, Madaghiele M. Biodegradable cellulose-based hydrogels: design and applications. Materials 2009;2:353-73.

[144] Helenius G, Backdahl H, Bodin A, Nannmark U, Gatenholm P, Risberg B. In vivo biocompatibility of bacterial cellulose. J Biomed Mater Res Part A 2006;76A:431-8.

[145] Du J, Hsieh Y. Cellulose/chitosan hybrid nanofibers from electrospinning of their ester derivatives. Cellulose 2009;16:247-60.

[146] Espinoza-Herrera N, Pedrosas-Islas R, Martin-Martinez ES, Cruz-Orea A, Tomes SA. Thermal, mechanical and microstructures properties of cellulose derivatives films: a comparative study. Food Biophys 2011;6:106-14.

[147] Czaja W, Krystynowicz A, Bielecki S, Brown Jr RM. Microbial cellulose-the natural power to heal wounds. Biomaterials 2006;27:145-51.

[148] Ferreira LM, Sobral CS, Blanes L, Ipolito MZ, Horibe EK. Proliferation of fibroblasts cultured on a hemi-cellulose dressing. J Plast Reconstr Aesthet Surg 2009;5:865-9.

[149] Jung K, Kim Y, Kim H, Jin H. Antimicrobial properties of hydrated cellulose membranes with silver nanoparticles. J Biomater Sci Polym Ed 2009;20:311-24.

[150] Serafica G, Mormino R, Oster GA, Lentz KE, Koehler KP. Microbial cellulose wound dressing for treating chronic, wounds. US7704523 B2 2010.

[151] Cullen MB, Silcock DW, Boyle C. Wound dressing comprising oxidized cellulose and human recombinat collagen. Patent US 20107833790 B2; 2010.

[152] d'Ayala GG, Malinconico M, Laurienzo P. Marine derived polysaccharides for biomedical applications: chemical modification approaches. Molecules 2008;13:2069-106

[153] Lee KY, Mooney DJ. Hydrogels for tissue engineering. Chem Rev 2001;101:1869-79.

[154] Boanini E, Rubini K, Panzavolta S, Bigi A. Chemico-physical characterization of gelatin films modified with oxidized alginate. Acta Biomater 2010;6:383-8.

[155] Jeon O, Powell C, Solorio LD, Krebs MD, Alsberg E. Affinity-based growth factor delivery using biodegradable, photocrosslinked heparin-alginate hydrogels. J Control Release 2011;154:258-66.

[156] Kim JO, Choi JY, Park JK, Kim JH, Jin SG, Chang SW, et al. Development of clindamycin-loaded wound dressing with polyvinyl alcohol and sodium alginate. Biol Pharm Bull 2008;31:2277-82.

[157] Han J, Zhou Z, Yin R, Yang D, Nie J. Alginate-chitosan/hydroxyapatite polyelectrolyte complex porous scaffolds: preparation and characterization. Int J Biol Macromol 2010;46:199-205.

[158] Foster AVM, Greenhill MT, Edmonds ME. Comparing two dressings in the treatment of diabetic foot ulcers. J Wound Care 1994;3:224-8.

[159] Tarun K, Gobi N. Calcium alginate/PVA blended nano fibre matrix for wound dressing. Indian J Fibre Text Res 2012;37:127-32.

[160] Lee CH, Singla A, Lee Y. Biomedical applications of collagen. Int J Pharm 2001;221:1-22.

[161] Valenta C, Auner BG. The use of polymers for dermal and transdermal delivery. Eur J Pharm Biopharm 2004;58:279-89.

[162] Arul V, Kartha R, Jayakumar R. A therapeutic approach for diabetic wound healing using biotinylated GHK incorporated collagen matrices. Life Sci 2007;80:275-84

[163] Parenteau-Bareil R, Gauvin R, Berthod F. Collagen-based biomaterials for tissue engineering applications. Materials 2010;3:1863-87.

[164] Cen L, Liu W, Cui L, Zhang W, Cao Y. Collagen tissue engineering: development of novel biomaterials and applications. Pediatr Res 2008;63:492-6.

[165] Lammers G, Tjabringa GS, Schalkwijk J, Daamen WF, van Kuppevelt TH. A molecularly defined array based on native fibrillar collagen for the assessment of skin tissue engineering biomaterials. Biomaterials 2009;30:6213-20.

[166] Antonio F, Guillem R, Sonia T, Clara M, Piergiorgio G, Valeria C, et al. Cross-linked collagen sponges loaded with plant polyphenols with inhibitory activity towards chronic wound enzymes. Biotechnol J 2011;6:1208-18.

[167] Lin Y, Tan F, Marra KC, Jan S, Liu D. Synthesis and characterization of collagen/ hyaluronan/chitosan composite sponges for potential biomedical applications. Acta Biomater 2009;5:2591-600.

[168] Zeugolis DI, Paul GR, Attenburrow G. Cross-linking of extruded collagen fibers-a biomimetic three-dimensional scaffold for tissue engineering applications. J Biomed Mater Res Part A 2009;89A:895-908.
169] Kondo S, Niiyama H, Yu A, Kuroyanagi Y. Evaluation of a wound dressing composed of hyaluronic acid and collagen sponge containing epidermal growth factor in diabetic mice. Journal of Biomaterials Science Polymer Edition 2011

[170] Lee CR, Grodzinsky AJ, Spector M. The effects of cross-linking of collagenglycosaminoglycan scaffolds on compressive stiffness, chondrocytemediated contraction, proliferation and biosynthesis. Biomaterials 2001;22:3145-54

[171] Chen ZG, Wang PW, Wei B, Mo XM, Cui FZ. Electrospun collagen-chitosan nanofiber: a biomimetic extracellular matrix for endothelial cell and smooth muscle cell. Acta Biomater 2010;6:372-82.

[172] Srinivasan A, Sehgal PK. Characterization of biocompatible collagen fibers-a promising candidate for cardiac patch. Tissue Eng Part C Methods 2010;16:895-903.

[173] Zhong SP, Zhang YZ, Lim CT. Tissue scaffolds for skin wound healing and dermal reconstruction. Nanomed Nanobiotechnol 2010;2:510-25.

[174] Liu X, Ma PX. Phase separation, pore structure, and properties of nanofibrous gelatin scaffolds. Biomaterials 2009;30:4094-103.

175] Gioffrè M, Torricelli P, Panzavolta S, Rubini K, Bigi A. Role of pH on stability and mechanical properties of gelatin films. J Bioact Compat Polym 2012;27:67-77.

[176] Grover CN, Cameron RE, Best SM. Investigating the morphological, mechanical and degradation properties of scaffolds comprising collagen, gelatin and elastin for use in soft tissue engineering. J Mech Behav Biomed Mater 2012;10:62-74.

177] Farris S, Song J, Huang O. Alternative reaction mechanism for the cross-linking of gelatin with glutaraldehyde. J Agric Food Chem 2010;58:998-1003.

178] Rujitanaroj P, Pimpha N, Supaphol P. Wound-dressing materials with antibacterial activity from electrospun gelatin fiber mats containing silve nanoparticles. Polym Degrad Stab 2008;49:4723-32.

[179] Panzavolta S, Gioffré M, Focarete ML, Gualandi C, Foroni L, Bigi A. Electrospun gelatin nanofibers: optimization of genipin cross-linking to preserve fiber morphology after exposure to water. Acta Biomater 2011;7:1702-9.

[180] Saha N, Saarai A, Roy N, Kitano T, Saha P. Polymeric biomaterial based hydrogels for biomedical applications. J Biomater Nanobiotechno 2011:2:85-90.

[181] Singh O, Gupta SS, Soni M, Moses S, Shukla S, Mathur RK. Collagen dressing versus conventional dressings in burn and chronic wounds: a retrospective study. J Cutan Aesthet Surg 2011;4:12-6.

[182] Arul V, Masilamoni JG, Jesudason EP, Jaji PJ, Inayathullah M, Dicky John DG et al. Glucose oxidase incorporated collagen matrices for dermal wound repair in diabetic rat models: a biochemical study. J Biomater Appl 2012;26:917-38.

[183] Adhirajan N, Shanmugasundaram N, Shanmuganathan S, Babu M. Collagenbased wound dressing for doxycycline delivery: in-vivo evaluation in an infected excisional wound model in rats. J Pharm Pharmacol 2009;61:1617-23.

[184] Manizate F, Fuller A, Gendics C, Lantis J. A prospective, single-center nonblinded, comparative, postmarket clinical evaluation of a bovinederived collagen with ionic silver dressing versus a carboxymethylcellulose and ionic silver dressing for the reduction of bioburden in variable-etiology, bilateral lower-extremity wounds. Adv Skin Wound Care 2012;25:220-5.

[185] Kawai K, Suzuki S, Tabata Y, Nishimura Y. Accelerated wound healing through the incorporation of basic fibroblast growth factor-impregnated gelatin microspheres into artificial dermis using a pressure-induced decubitus ulcer model in genetically diabetic mice. Br J Plast Surg 2005;58:1115-23.

[186] Kanda N, Morimoto N, Ayvazyan AA, Takemoto S, Kawai K, Nakamura Y, et al Evaluation of a novel collagen-gelatin scaffold for achieving the sustained release of basic fibroblast growth factor in a diabetic mouse model. J Tissue Eng Regenerative Med 2012.

[187] Ahmed TAE, Dare EV, Hincke M. Fibrin: a versatile scaffold for tissue engineering applications. Tissue Eng Part B 2008;14:199-245.

[188] Chen TM, Tsai JC, Burnouf T. A novel technique combining platelet gel, skin graft, and fibrin glue for healing recalcitrant lower extremity ulcers. Dermato Surg 2010;36:453-60.

[189] Pedroso DC, Tellechea A, Moura L, Fidalgo-Carvalho I, Duarte J, Carvalho E et al. Improved survival, vascular differentiation and wound healing potentia of stem cells co-cultured with endothelial cells. PLoS ONE 2011;6:1-12.

[190] Hasmann A, Gewessler U, Hulla E, Schneider KP, Binder B, Francesko A, et al Sensor materials for the detection of human neutrophil elastase and cathepsin G activity in wound fluid. Exp Dermatol 2011;20:508-13.

[191] Ruge M. Evaluation of the effect of Vivostat Platelet Rich Fibrin (PRF) in the treatment of diabetic foot ulcers. wwwclinicaltrialsgov (last accessed October 2012) 2011; NCT00770939.

[192] Mandal BB, Kundu SC. Cell proliferation and migration in silk fibroin 3D scaffolds. Biomaterials 2009;30:2956-65.

[193] Inpanya P, Faikrua A, Ounaroon A, Sittichokechaiwut A, Viyoch J. Effects of the blended fibroin/aloe gel film on wound healing in streptozotocin-induced diabetic rats. Biomed Mater 2012;7:035008.

194] Dash R, Ghosh SK, Kaplan DL, Kundu SC. Purification and biochemica characterization of a $70 \mathrm{kDa}$ sericin from tropical tasar silkworm, Antheraea mylitta. Comp Biochem Physiol B Biochem Mol Biol 2007;147:129-34.

[195] Baldwin AD, Kiick KL. Polysaccharide-modified synthetic polymeric biomaterials. Biopolymers 2010;94:128-40. 
[196] Hwang MR, Kim JO, Lee JH, Kim YI, Kim JH, Chang SW, et al. Gentamicinloaded wound dressing with polyvinyl alcohol/dextran hydrogel: gel characterization and in vivo healing evaluation. AAPS PharmSciTech 2010;11:1092-103.

[197] Sun G, Zhang X, Shen Y, Sebastian R, Dickinson LE, Fox-Talbot K, et al. Dextran hydrogel scaffolds enhance angiogenic responses and promote complete skin regeneration during burn wound healing. PNAS 2011;108:20976-81.

[198] Parulkar BG, Sobti MK, Pardanani DS. Dextranomer dressing in the treatment of infected wounds and cutaneous ulcers. J Postgrad Med 1985;31:28-33.

[199] Koria P, Yagi H, Kitagawa Y, Megeed Z, Nahmias Y, Sheridan R, et al. Selfassembling elastin-like peptides growth factor chimeric nanoparticles for the treatment of chronic wounds. Proc Natl Acad Sci USA 2011;108:1034-9.

[200] Vasconcelos A, Gomes AC, Cavaco-Paulo A. Novel silk fibroin/elastin wound dressings. Acta Biomater 2012;8:3049-60.

[201] Daamen WF, Veerkamp JH, van Hest JC, van Kuppevelt TH. Elastin as a biomaterial for tissue engineering. Biomaterials 2007;28:4378-98.

[202] Mithieux SM, Rasko JEJ, Weiss ASAS. Synthetic elastin hydrogels derived from massive elastic assemblies of self-organized human protein monomers Biomaterials 2004;25:4921-7.

[203] Leach JB, Wolinsky JB, Stone PJ, Wong JY. Crosslinked alpha-elastin biomaterials: towards a processable elastin mimetic scaffold. Acta Biomater 2005;1:155-64.

[204] McHale MK, Setton LA, Chilkoti A. Synthesis and in vitro evaluation of enzymatically cross-linked elastin-like polypeptide gels for cartilaginous tissue repair. Tissue Eng Part A 2005;11:1768-79.

[205] Mithieux SM, Tu Y, Korkmaz E, Braet F, Weiss AS. In situ polymerization of tropoelastin in the absence of chemical cross-linking. Biomaterials 2009;30:431-5.

[206] Wise SG, Mithieux SM, Weiss AS. Engineered tropoelastin and elastin-based biomaterials. Adv Protein Chem Struct Biol 2006;78:1-24.

[207] Bourke SL, Al-Khalili M, Briggs T, Michniak BB, Kohn J, Poole-Warren LA. A photo-crosslinked poly(vinyl alcohol) hydrogel growth factor release vehicle for wound healing applications. AAPS PharmSci 2003;5:E33.

[208] Varshney L. Role of natural polysaccharides in radiation formation of PVAhydrogel wound dressing. Nucl Instrum Methods Phys Res Sect B 2007;255:343-9.

[209] Kim JO, Park JK, Kim JH, Jin SG, Yong CS, Li DX, et al. Development of polyvinyl alcohol-sodium alginate gel-matrix-based wound dressing system containing nitrofurazone. Int J Pharm 2008;359:79-86.

[210] Xia C, Xiao C. Preparation and characterization of dual responsive sodium alginate-g-poly(vinyl alcohol) hydrogel. J Appl Polym Sci 2012;123: 2244-9.

[211] de Souza Costa-Junior E, Pereira MM, Mansur HS. Properties and biocompatibility of chitosan films modified by blending with PVA and chemically crosslinked. Journal of Materials Science Materials in Medicine 2009;20:553-61.

[212] Linh NTB, Min YK, Song H, Lee B. Fabrication of polyvinyl alcohol/gelatin nanofiber composites and evaluation of their material properties. J Biomed Mater Res Part B 2010;95B:184-91.

[213] Fathi E, Atyabi N, Imani M, Alinejad Z. Physically crosslinked polyviny alcohol-dextran blend xerogels: morphology and thermal behavior. Carbohydr Polym 2011;84:145-52.

[214] Drury JL, Mooney DJ. Hydrogels for tissue engineering: scaffold design variables and applications. Biomaterials 2003;24:4337-51.

[215] Masters KS, Leibovich SJ, Belem P, West JL, Poole-Warren LA. Effects of nitric oxide releasing poly(vinyl alcohol) hydrogel dressings on dermal wound healing in diabetic mice. Wound Repair and Regeneration: Official Publication of the Wound Healing Society [and] the European Tissue Repair Society 2002;10:286-94.

[216] Manju S, Antony M, Sreenivasan K. Synthesis and evaluation of a hydrogel that binds glucose and releases ciprofloxacin. J Mater Sci 2010:45:4006-12.

[217] Zhu J. Biactive modification of poly(ethylene glycol) hydrogels for tissue engineering. Biomaterials 2010;31:4639-56.

[218] Gibas I, Janik H. Review: synthetic polymer hydrogels for biomedical applications. Chem Chem Technol 2010;4:297-304

[219] Peppas NA, Keys KB, Torres-Lugo M, Lowman AM. Poly(ethylene glycol)containing hydrogels in drug delivery. J Controlled Release 1999;62:81-7.

[220] Beamish JA, Zhu J, Kottke-Marchant K, Marchant RE. The effects of monoacrylated poly(ethylene glycol) on the properties of poly(ethylene glycol) diacrylate hydrogels used for tissue engineering. J Biomed Mater Res Part A 2010;92:441-50.

[221] Metters A, Hubbell J. Network formation and degradation behavior of hydrogels formed by Michael-type addition reactions. Biomacromolecules 2005;6:290-301.

[222] Sanborn TJ, Messersmith PB, Barron AE. In situ crosslinking of a biomimetic peptide-PEG hydrogel via thermally triggered activation of factor XIII Biomaterials 2002;23:2703-10.

[223] Sun G, Zhang X, Chu C. Effect of molecular weight of polyethylene glycol (PEG) on the properties of chitosan-PEG-poly (N-isopropylacrymide) hydrogels. J Mater Sci Mater Med 2008;19:2865-72.

[224] Sokolsky-Papkov M, Agashi K, Olaye A, Shakesheff K, Domb AJ. Polymer carriers for drug delivery in tissue engineering. Adv Drug Deliv 2007;59:187-209.

[225] Lee PY, Cobain E, Huard J, Huang L. Thermosensitive hydrogel PEG-PLGA-PEG enhances engraftment of muscle-derived stem cells and promotes healing in diabetic wound. Mol Ther 2007;15:1189-94.
[226] Yang Y, Xia T, Chen F, Wei W, Liu C, He S, et al. Electrospun fibers with plasmid bFGF polyplex loadings promote skin wound healing in diabetic rats. Mol Pharm 2012;9:48-58.

[227] Huang Z, Lu M, Zhu G, Gao H, Xie L, Zhang X, et al. Acceleration of diabeticwound healing with PEGylated rhaFGF in healing-impaired streptozocin diabetic rats. Wound Repair and Regeneration: Official Publication of the Wound Healing Society [and] the European Tissue Repair Society 2011;19:633-44.

[228] Biazar E, Roveimiab Z, Shahhosseini G, Khataminezhad M, Zafari M, Majdi A. Biocompatibility evaluation of a new hydrogel dressing based on polyvinylpyrrolidone/polyethylene glycol. J Biomed Biotechnol 2012;2012:343989.

[229] Choi JS, Leong KW, Yoo HS. In vivo wound healing of diabetic ulcers using electrospun nanofibers immobilized with human epidermal growth factor (EGF). Biomaterials 2008;29:587-96.

[230] Choi JS, Choi SH, Yoo HS. Coaxial electrospun nanofibers for treatment of diabetic ulcers with binary release of multiple growth factors. J Mater Chem 2011;21:5258-67.

[231] Himly N, Darwis D, Hardiningsih L. Poly(n-vinylpyrrolidone) hydrogels: Hydrogel composites as wound dressing for tropical environment. Radiat Phys Chem 1993;42:911-4.

[232] Lugão AB, Machado LDB, Miranda LF, Alvarez MR, Rosiak JM. Study of wound dressing structure and hydration/dehydration properties. Radiat Phys Chem 1998;52:319.

[233] Lugão AB, Rogero SO, Malmonge SM. Rheological behaviour of irradiated wound dressing poly(vinyl pyrrolidone) hydrogels. Radiat Phys Chem 2002;63:543-6.

[234] Li Y, Lee PI. Controlled nitric oxide delivery platform based on S-nitrosothiol conjugated interpolymer complexes for diabetic wound healing. Mol Pharm 2010:7:254-66.

[235] Naira LS, Laurencin CT. Biodegradable polymers as biomaterials. Prog Polym Sci 2007;32:762-98.

[236] Lee J, Cho Y, Lee J, Kim H, Pyun D, Park M, et al. Preparation of wound dressing using hydrogel polyurethane foam. Trends Biomater Artif Organs 2001;15:4-6.

[237] Chen Z, Lu H. Constructing sacrificial bonds and hidden lengths for ductile graphene/polyurethane elastomers with improved strength and toughness. J Mater Chem 2012;22:12479-90.

[238] Varma AK, Bal A, Kumar H, Kesav R, Nair S. Efficacy of polyurethane foam dressing in debrided diabetic lower limb wounds. Wounds 2008;12:5-8.

[239] Shi R, Chen D, Liu Q, Wu Y, Xu X, Zhang L, et al. Recent advances in synthetic bioelastomers. Int J Mol Sci 2009;10:4223-56.

[240] Khil MS, Cha DI, Kim HY, Kim IS, Bhattarai N. Electrospun nanofibrous polyurethane membrane as wound dressing. J Biomed Mater Res B Appl Biomater 2003;67:675-9.

[241] Davis FJ, Mitchell GR. Polyurethane based materials with application in medical devices. Biomater Prototyping Appl Med 2008;3:27-48.

[242] Shah CB, Swaniker B, Dowd BJ, Brandon B. Efficacy and mode of action of a new PHMB impregnated polyurethane foam dressing. Covidien 2009;10:1-8.

[243] Barrett S. Mepilex Ag: an antimicrobial, absorbent foam dressing with Safetac technology. Br J Nurs 2009;18:S28-36.

[244] Radhakumary C, Nandkumar AM, Nair PD. Hyaluronic acid-g-poly(HEMA) copolymer with potential implications for lung tissue engineering. Carbohydr Polym 2011;85:439-45.

[245] Tsou T, Tang S, Huang Y, Wu J, Young J, Wang H. Poly(2-hydroxyethyl methacrylate) wound dressing containing ciprofloxacin and its drug release studies. J Mater Sci Mater Med 2005;16:95-100.

[246] Halpenny GM, Steinhardt RC, Okialda KA, Mascharak PK. Characterization of pHEMA-based hydrogels that exhibit light-induced bactericidal effect via release of NO. J Mater Sci Mater Med 2009;20:2353-60.

[247] Rayment EA, Dargaville T, Upton Z. Wound repair composition and method. Patent 201001728602010.

[248] Wang D, Song YP, Lin L, Wang X, Wang Y. A novel phosphorus-containing poly(lactic acid) toward its flame retardation. Polymer 2011;52:233-8.

[249] Ignatova M, Manolova N, Markova N, Rashkov I. Electrospun non-woven nanofibrous hybrid mats based on chitosan and PLA for wound-dressing applications. Macromol Biosci 2009;9:102-11.

[250] Armentano I, Dottori M, Fortunati E, Mattioli S, Kenny JM. Biodegradable polymer matrix nanocomposites for tissue engineering: a review. Polym Degrad Stab 2010;95:2126-46.

[251] Li S. Hydrolytic degradation characteristics of aliphatic polyesters derived from lactic and glycolic acids. J Biomed Mater Res Part B Appl Biomater 1999;48:342-53.

[252] Dong X, Xu J, Wang W, Luo H, Liang X, Zhang L, et al. Repair effect of diabetic ulcers with recombinant human epidermal growth factor loaded by sustained-release microspheres. Sci China C Life Sci 2008;51:1039-44.

[253] Chu Y, Yu D, Wang P, Xu J, Li D, Ding M. Nanotechnology promotes the fullthickness diabetic wound healing effect of recombinant human epidermal growth factor in diabetic rats. Wound Repair and Regeneration: Official Publication of the Wound Healing Society [and] the European Tissue Repair Society 2010;18:499-505.

[254] Xu X, Zhong W, Zhou S, Trajtman A, Alfa M. Electrospun PEG-PLA nanofibrous membrane for sustained release of hydrophilic antibiotics. J Appl Polym Sci 2010;118:588-95.

[255] Merrel JG, McLaughlin SW, Tie L, Laurencin CT, Chen AF, Nair LS. Curcuminloaded poly( $\varepsilon$-caprolactone) nanofibres: diabetic wound dressing with anti- 
oxidant and anti-inflammatory properties. Clin Exp Pharmacol Physiol 2009;36:1149-56.

[256] Kang X, Xie Y, Powell HM, James Lee L, Belury MA, Lannutti JJ, et al. Adipogenesis of murine embryonic stem cells in a three-dimensional culture system using electrospun polymer scaffolds. Biomaterials 2007;28:450-8.

[257] Galiano RD, Tepper OM, Pelo CR, Bhatt KA, Callaghan M, Bastidas N, et al. Topical vascular endothelial growth factor accelerates diabetic wound healing through increased angiogenesis and by mobilizing and recruiting bone marrow-derived cells. Am J Pathol 2004;164:1935-47.

[258] Li H, Fu X, Zhang L, Huang Q, Wu Z, Sun T. Research of PDGF-BB gel on the wound healing of diabetic rats and its pharmacodynamics. J Surg Res 2008; $145: 41-8$

[259] Uchi H, Igarashi A, Urabek Koga T,, Nakayama J, Kawamori R, et al. Clinical efficacy of basic fibroblast growth factor (bFGF) for diabetic ulcer. Eur J Dermatol 2009;19:461-8.

[260] Gallagher KA, Liu ZJ, Xiao M, Chen H, Goldstein LJ, Buerk DG, et al. Diabetic impairments in NO-mediated endothelial progenitor cell mobilization and homing are reversed by hyperoxia and SDF-1 alpha. J Clin Invest 2007; 117:1249-59.

[261] Kwon DS, Gao X, Liu YB, Dulchavsky DS, Danyluk AL, Bansal M, et al. Treatment with bone marrow-derived stromal cells accelerates wound healing in diabetic rats. Int Wound J 2008:5:453-63.

[262] Barcelos LS, Duplaa C, Krankel N, Graiani G, Invernici G, Katare R, et al. Human CD133+ progenitor cells promote the healing of diabetic ischemic ulcers by paracrine stimulation of angiogenesis and activation of Wnt signaling. Circ Res 2009;104:1095-102.

[263] Amos PJ, Kapur SK, Stapor PC, Shang H, Bekiranov S, Khurgel M, et al. Human adipose-derived stromal cells accelerate diabetic wound healing: impact of cell formulation and delivery. Tissue Eng Part A 2010;16:1595-606.

[264] Lee KB, Choi J, Cho SB, Chung JY, Moon ES, Kim NS, et al. Topical embryonic stem cells enhance wound healing in diabetic rats. J Orthop Res 2011;29:1554-62.

[265] Asai J, Takenaka H, Ii M, Asahi M, Kishimoto S, Katoh N, et al. Topical application of ex vivo expanded endothelial progenitor cells promotes vascularisation and wound healing in diabetic mice. Int Wound J 2012.

[266] Keswani SG, Katz AB, Lim FY, Zoltick P, Radu A, Alaee D, et al. Adenoviral mediated gene transfer of PDGF-B enhances wound healing in type I and type II diabetic wounds. Wound Repair Regen 2004;12:497-504.

[267] Badillo AT, Chung S, Zhang L, Zoltick P, Liechty KW. Lentiviral gene transfer of SDF-1alpha to wounds improves diabetic wound healing. J Surg Res 2007; 143:35-42.

[268] Mohebali K, Ro P, Young DM, Boudreau N, Hansen SL. Transfer of Hox B3 gene accerelates wound healing in diabetic mice. J Am Coll Surg 2008;207:S58.

[269] Cheng CF, Sahu D, Tsen F, Zhao Z, Fan J, Kim R, et al. A fragment of secreted Hsp90alpha carries properties that enable it to accelerate effectively both acute and diabetic wound healing in mice. J Clin Invest $2011 ; 121: 4348-61$.

[270] Gibran NS, Jang YC, Isik FF, Greenhalgh DG, Muffley LA, Underwood RA, et al. Diminished neuropeptide levels contribute to the impaired cutaneous healing response associated with diabetes mellitus. J Surg Res 2002;108: $122-8$.

[271] Scott JR, Tamura RN, Muangman P, Isik FF, Xie C, Gibran NS. Topical substance $P$ increases inflammatory cell density in genetically diabetic murine wounds. Wound Repair Regen 2008;16:529-33.

[272] Hamed S, Ullmann Y, Masoud M, Hellou E, Khamaysi Z, Teot L. Topical erythropoietin promotes wound repair in diabetic rats. J Invest Dermatol 2010;130:287-94.

[273] Apikoglu-Rabus S, Izzettin FV, Turan P, Ercan F. Effect of topical insulin on cutaneous wound healing in rats with or without acute diabetes. Clin Exp Dermatol 2010;35:180-5

[274] Fujita N, Sagaguchi I, Kobayashi H, Ikeda N, Kato Y, Minamino M. An extract of the root of Lithospermun erythrorhison accelerates wound healing in diabetic mice. Biol Pharm Bull 2003;26:329-35.

[275] Lau TW, Lam FF, Lau KM, Chan YW, Lee KM, Sahota DS, et al. Pharmacological investigation on the wound healing effects of Radix rehmanniae in an animal model of diabetic foot ulcer. J Ethnopharmacol 2009;123:155-62.

[276] Abu-Al-Basal MA. Healing potential of Rosmarinus officinalis L. on fullthickness excision cutaneous wounds in alloxan-induced-diabetic BALB/c mice. J Ethnopharmacol 2010;131:443-50.

[277] Dwivedi VK, Chaudhary M. Comparative wound healing efficacy of ampucare and becaplermin in diabetic rat. Afr J Pharm Pharmacol 2012;6:883-92.
[278] Ponrasu T, Suguna L. Efficacy of Annona squamosa on wound healing in streptozotocin-induced diabetic rats. Int Wound J 2012;9:613-23.

[279] Jacobi J, Jang JJ, Sundram U, Dayoub H, Fajardo LF, Cooke JP. Nicotine accelerates angiogenesis and wound healing in genetically diabetic mice. Am J Pathol 2002;161:97-104.

[280] Bitto A, Minutoli L, Altavilla D, Polito F, Fiumara T, Marini H, et al. Simvastatin enhances VEGF production and ameliorates impaired wound healing in experimental diabetes. Pharmacol Res 2008;57:159-69.

[281] Bagheri M, Jahromi BM, Mirkhani H, Solhjou Z, Noorafshan A, Zamani A, et al Azelnidipine, a new calcium channel blocker, promotes skin wound healing in diabetic rats. J Surg Res 2011;169:e101-7.

[282] Ko SH, Nauta A, Morrison SD, Zhou H, Zimmermann A, Gurtner GC, et al. Antimycotic ciclopirox olamine in the diabetic environment promotes angiogenesis and enhances wound healing. PLoS ONE 2011;6:e27844.

[283] McLaughlin PJ, Pothering CA, Immonen JA, Zagon IS. Topical treatment with the opioid antagonist naltrexone facilitates closure of full-thickness wounds in diabetic rats. Exp Biol Med 2011;236:1122-32.

[284] Wang W, Lin S, Xiao Y, Huang Y, Tan Y, Cai L, et al. Acceleration of diabetic wound healing with chitosan-crosslinked collagen sponge containing recombinant human acidic fibroblast growth factor in healing-impaired STZ diabetic rats. Life Sci 2008;82:190-204.

[285] Ben-shalom N, Zvi N, Abraham P, Dror R. Novel injectable chitosan mixtures forming hydrogels. EP2121026 2009.

[286] Zhang H, Qadeer A, Chen W. In situ gelable interpenetrating double network hydrogel formulated from binary components: thiolated chitosan and oxidized dextran. Biomacromolecules 2011;12:1428-37.

[287] Lobmann R, Pittasch D, Muhlen I, Lehnert H. Autologous human keratinocytes cultured on membranes composed of benzyl ester of hyaluronic acid for grafting in nonhealing diabetic foot lesions: a pilot study. J Diabetes Complications 2003;17:199-204

[288] Scherer SS, Pietramaggiori G, Matthews J, Perry S, Assmann A, Carothers A et al. Poly-N-acetyl glucosamine nanofibers: a new bioactive material to enhance diabetic wound healing by cell migration and angiogenesis. Ann Surg 2009;250:322-30.

[289] Sobotka L, Smahelova A, Pastorova J, Kusalova M. A case report of the treatment of diabetic foot ulcers using a sodium hyaluronate and iodine complex. Int J Low Extrem Wounds 2007;6:143-7.

[290] Pietramaggiori G, Yang H, Scherer SS, Kaipainen A, Chan R, Alperovich MBS et al. Effects of poly-N-acetyl glucosamine (pGlcNAc) patch on wound healing in $\mathrm{db} / \mathrm{db}$ Mouse. J Trauma Acute Care Surg 2008;64:803-8.

[291] Bayaty F, Abdulla M, Hassan MIA, Masud M. Wound healing potential by hyaluronate gel in streptozotocin-induced diabetic rats. Sci Res Essays 2010;5:2756-60

[292] Abbruzzese L, Rizzo L, Fanelli G, Tedeschi A, Scatena A, Goretti C, et al. A Effectiveness and safety of a novel gel dressing in the management of neuropathic leg ulcers in diabetic patients: a prospective double-blind randomized trial. Int J Low Extrem Wounds 2009;8:134-40.

[293] Lazaro-Martinez JL, Aragon-Sanchez JV, Garcia-Morales E, BeneitMontesinos JV, Gonzalez-Jurado M. A retrospective analysis of the costeffectiveness of a collagen/oxidized regenerated cellulose dressing in the treatment of neuropathic diabetic foot ulcers. Ostomy/Wound Manage 2010;56:4-8

[294] Ulrich D, Smeets R, Unglaub F, Woltje M, Pallua N. Effect of oxidized regenerated cellulose/collagen matrix on proteases in wound exudate of patients with diabetic foot ulcers. J Wound Ostomy and Continence Nurs 2011;38:522-8.

[295] Choi DS, Kim S, Lim Y, Gwon H. Hydrogel incorporated with chestnut honey accelerates wound healing and promotes early HO-1 protein expression in diabetic (db/db) mice. Tissue Eng Regenerat Med 2012;9:36-42.

[296] Shaw J, Hughes CM, Lagan KM, Stevenson MR, Irwin CR, Bell PM. The effect of topical phenytoin on healing in diabetic foot ulcers: a randomized controlled trial. Diabet Med 2011;28:1154-7.

[297] Molan P. Honey based wound dressings. USRE42755 E 2011.

[298] Iorio ML, Goldstein J, Adams M, Steinberg J, Attinger C. Functional limb salvage in the diabetic patient: the use of a collagen bilayer matrix and risk factors for amputation. Plast Reconstr Surg 2011;127:260-7.

[299] Jorgensen B, Karlsmark T, Vogensen H, Haase L, Lundquist R. A pilot study to evaluate the safety and clinical performance of Leucopatch, an autologous, additive-free, platelet-rich fibrin for the treatment of recalcitrant chronic wounds. Int J Low Extrem Wounds 2011;10:218-23. 